DEMOGRAPHIC RESEARCH

VOLUME 40, ARTICLE 14, PAGES 359-394

PUBLISHED 22 FEBRUARY 2019

https://www.demographic-research.org/Volumes/Vol40/14/

DOI: 10.4054/DemRes.2019.40.14

Research Article

'Will the one who keeps the children keep the house?' Residential mobility after divorce by parenthood status and custody arrangements in France

\title{
Giulia Ferrari
}

\section{Carole Bonnet}

\section{Anne Solaz}

This publication is part of the Special Collection on "Separation, Divorce, and Residential Mobility in a Comparative Perspective," organized by Guest Editors Júlia Mikolai, Hill Kulu, and Clara Mulder.

(C) 2019 Giulia Ferrari, Carole Bonnet \& Anne Solaz.

This open-access work is published under the terms of the Creative Commons Attribution 3.0 Germany (CC BY 3.0 DE), which permits use, reproduction, and distribution in any medium, provided the original author(s) and source are given credit.

See https://creativecommons.org/licenses/by/3.0/de/legalcode. 


\section{Contents}

$1 \quad$ Introduction $\quad 360$

$2 \quad$ Background 361

$2.1 \quad$ Residential mobility and parental status $\quad 361$

$2.2 \quad$ Residential mobility and custodial status 362

$2.3 \quad$ Consequences of the move 364

2.3.1 The distance of the move 364

2.3.2 Housing conditions 365

$3 \quad$ The French context 365

$4 \quad$ Data, methods, and variables $\quad 367$

4.1 Data and sample $\quad 367$

$\begin{array}{lll}4.2 & \text { Methods } & 368\end{array}$

$\begin{array}{lll}4.3 & \text { Variables } & 369\end{array}$

$\begin{array}{lll}4.3 .1 & \text { Outcomes } & 369\end{array}$

$\begin{array}{lll}\text { 4.3.2 } & \text { Variables of interest } & 369\end{array}$

$\begin{array}{lll}\text { 4.3.3 Controls } & 370\end{array}$

$5 \quad$ Results $\quad 371$

$\begin{array}{lll}5.1 & \text { Descriptive statistics } & 371\end{array}$

$5.2 \quad$ Multivariate analysis 373

5.2.1 Moving after divorce $\quad 373$

$\begin{array}{lll}\text { 5.2.2 } & \text { Moving distance } & 377\end{array}$

$\begin{array}{lll}5.2 .3 & \text { Housing conditions } & 378\end{array}$

$\begin{array}{lll}5.3 & \text { Endogeneity issues } & 381\end{array}$

$6 \quad$ Discussion and conclusions $\quad 381$

$7 \quad$ Acknowledgements 384

$\begin{array}{ll}\text { References } & 385\end{array}$

$\begin{array}{ll}\text { Appendix } & 389\end{array}$ 


\title{
'Will the one who keeps the children keep the house?' Residential mobility after divorce by parenthood status and custody arrangements in France
}

\author{
Giulia Ferrari ${ }^{1}$ \\ Carole Bonnet ${ }^{2}$ \\ Anne Solaz ${ }^{2}$
}

\begin{abstract}

\section{BACKGROUND}

After divorce, at least one of the partners usually relocates and, according to past research, it is more often the woman. Women's housing conditions are likely to worsen. Divorces where children are involved are frequent and shared custody arrangements are becoming more common in Europe.
\end{abstract}

\section{OBJECTIVE}

This paper analyses the extent to which residential mobility after divorce is linked to parental status and child custody arrangements in France, a topic that remains largely unstudied. We assess not only the probability of moving but also the distance of the move and changes in housing conditions.

\section{METHODS}

We apply logistic and linear regressions to different indicators from a recent administrative database, the French Permanent Demographic Sample, 2010-2013, which makes it possible to track divorced people and their households over time.

\section{RESULTS}

One year after divorce, women are more likely to move than men, although the gender gap is narrower for parents. While sole custody is associated with fewer moves than noncustody for both sexes, shared custody arrangements imply many more moves for mothers than for fathers. Parents more often move near their previous joint home than nonparents, especially those with shared custody. Housing conditions do not necessarily deteriorate after separation, but women are often disadvantaged compared with men.

\footnotetext{
${ }^{1}$ Institut National d’Études Démographiques (INED), Paris, France. Email: giulia.ferrari@ined.fr.

${ }^{2}$ Institut National d'Études Démographiques (INED), Paris, France.
} 


\section{CONTRIBUTION}

This paper expands on the current literature in that it addresses changes in residency after separation by including the effects of parental status and child custody arrangements.

\section{Introduction}

Divorce has become a common life event that affects an ever-increasing share of the population in most developed countries. The stigma previously associated with divorce is less pronounced (Wolfinger 1999; Lyngstad and Jalovaara 2010) and the negative consequences of separation on well-being are more limited or of shorter duration than previously, for both adults (Hetherington 2003; Andreß and Bröckel 2007) and children (Amato 2001). However, the period around divorce remains a time of considerable difficulty and stress for most individuals (Amato 2010). Part of this stress is linked to the residential relocation that divorce entails. At the time of separation, partners must either look for a new home and agree on who will move or decide whether the joint home is to be sold. The new housing may be worse because of financial, parental, or professional constraints. Relocation may also involve a possible loss of social contacts with friends and neighbours.

Divorce frequently involves children, in which case parents must also make custody arrangements. A growing trend towards shared custody has been observed in many countries (Cancian et al. 2014), supported by new laws encouraging an equal division of parental responsibilities. This has certainly been the case in France, where more than one in five divorces that involve children result in shared custody arrangements, while the most common arrangement, in which the mother has sole custody, is on the decrease (Bonnet, Garbinti, and Solaz 2015). These trends may shape the residential mobility of divorced parents in the future, because shared custody implies that both parents must provide housing for their children on a regular basis. This means that they need to have enough space in their home and also live close to each other, especially when the children are young. Child custody arrangements, decided by the parents and submitted for the approval of a family court judge in France, may also be guided by the postdivorce housing conditions of each parent. Child custody arrangements and mobility choices are thus closely linked (Thomas, Mulder, and Cooke 2017).

In most cases, divorce involves the relocation of at least one partner. According to Durier (2017), only $20 \%$ of divorces involve simultaneous moves by both partners within the year following separation, meaning that one parent typically leaves the joint 
home before the other. Parents may have reasons for staying in the same accommodation or area that do not apply to childless partners, such as wanting to limit the changes associated with separation, whether for their children or because they have other financial constraints. Several questions therefore arise. Do divorcing parents and childless couples have different patterns of behaviour as regards moving? Is the father or the mother more likely to move out of the joint home? Is the move due to gender or custodial status? What are the characteristics of these moves: for example, distance from previous home, housing tenure, house size?

Using an extensive administrative database, we consider the factors that determine residential moves and the conditions of the new housing (if any) for married couples and civil unions (or PACS ${ }^{3}$ ) that have recently been dissolved in France. The current study investigates only the dissolutions of formal unions. ${ }^{4}$ It makes two primary contributions. First, it documents short-term mobility following divorce in France for parents relative to nonparents, which is novel because, apart from Villaume (2016), most of the available evidence is limited and outdated (Festy 1988; Bonvalet 1993). Second, in the context of an increasing trend in Europe towards shared custody, the originality of our work lies in expanding on the current literature, specifically regarding the determining factors and the types of moves that occur after separation. We do this by studying the specific role played by child custody arrangements following divorce.

\section{Background}

\subsection{Residential mobility and parental status}

The literature has studied what happens when divorce triggers a change in residence for at least one of the partners in the relationship (Sullivan 1986; Symon 1990; Feijten and van Ham 2007), emphasizing that divorce-related residential mobility has specific characteristics that differ from mobility linked to other family reasons (e.g., union formation or childbirth). First, the moves are often made in haste (Feijten and van Ham 2007), as a sense of urgency may affect the way the house is sold or induce some

\footnotetext{
${ }^{3}$ The French Civil Code Act of 15 November 1999, which has since been amended several times, provides the opportunity for unmarried couples to organize their lives together, with some social and tax advantages to both partners. A civil union or PACS (pacte civil de solidarité) may be established by a private or notarial act. It is registered at the district court where the partners jointly reside.

${ }^{4}$ The only way to identify cohabiting unions is by linking tax data to census data (which includes a question about unregistered partnership). However, due to the rotating nature of the French census, this is not possible on a yearly basis. Throughout the text, we will use the terms 'divorce' and 'separation' interchangeably, because we are considering official dissolutions of the two types of formal unions that are available in France, namely marriages and PACS.
} 
suboptimal choice of new accommodation. Second, the moves may be financially constrained, since separation brings an end to the household's economies of scale and, in many cases, may also lead to a decrease in living standards, especially for women (see Bonnet, Garbinti, and Solaz 2016 for France).

Moreover, the move may be spatially constrained because of the presence of children, who can affect both the occurrence of a move and the geographical destination (Mulder and Wagner 2010). Due to the parents' desire not to unsettle the children even more, they may attempt to ensure that their daily lives are as similar as possible to before the divorce by keeping them in the same home - or at least in the same school. Of course, the financial constraints (possibly faced by one parent more than the other) can be particularly significant after divorce and may force one or both parents to leave the joint home. Whatever their custodial status, parents are likely to stay closer to each other if they want to maintain the parent-child relationship.

Hypothesis 1: We expect parents either to remain in the joint home or to move closer to it more often than is the case for nonparents.

\subsection{Residential mobility and custodial status}

The literature, both theoretical and empirical, has paid much attention to which of the two partners moves out, a topic which - even when children are not involved - clearly has a gender dimension. Among parents, it is closely related to custodial status, because women are much more likely to be the custodial parent. In this article, we go further by trying to establish whether gender disparity in residential mobility is linked to custodial status.

Building on a theoretical cost-benefit approach, Mulder and Wagner (2010) study which parent moves out of the joint home following separation. The 'mover' is the one for whom the cost (monetary and nonmonetary) of moving is lower than the cost of staying. We expect the custodial parent to bear a higher cost - both monetary and nonmonetary - of moving from the joint home than the noncustodial parent. Mulder and Wagner identify three types of nonmonetary costs: housing disruption, which is associated with the risk of a decline in housing conditions; the effort of finding new accommodation and getting used to a new environment; and emotional distress. These costs may be higher for custodial parents compared with noncustodial parents, because relocation may affect the child(ren), who may lose some friends and, if the move involves changing schools, have to adjust to new schoolmates or changes in extracurricular activities. These developments could have some short-term negative 
effects on educational performance, although not necessarily in the long term (Hango 2006).

Hypothesis 2: The cost-benefit approach predicts that the custodial parent is more likely to stay in the joint home than the noncustodial parent following separation.

Remaining in the joint home requires sufficient resources to pay all the housing costs after divorce, whereas, in the case of moving, it is possible to choose somewhere smaller and therefore cheaper because of the reduced family size. So we may expect the parent with more financial resources to remain in the house, which would be in line with their greater bargaining power (Mulder et al. 2012).

Because custodial parents bear the largest share of child-related costs, which are only partly balanced by the child support payment given by the noncustodial parent, their relative resources compared with the noncustodial parent are diminished. Thus, custodial parents are less likely to remain in the joint home. On the other hand, if we include the bargaining power on certain nonfinancial aspects, such as the ability to make decisions regarding the daily lives of the children, the custodial parent may be considered to have more bargaining power than the noncustodial one. He or, in most cases, she may advocate for "the best interests of the child," which primarily means remaining in the joint home. A family court judge may support these "best interests" by deciding to keep the child in the joint home. These nonfinancial aspects may play a greater role than financial ones, thus reducing the influence of relative financial resources in sole custody arrangements. In shared custody arrangements, however, where these nonfinancial aspects are split equally, the parents' relative financial resources may play a larger role.

These considerations help us understand the interrelationships of gender, custodial status, and mobility, while possibly allowing us to disentangle the influence of gender from that of custodial status. On the one hand, because women are on average financially less well-off following divorce, they may be more likely to move out of the joint home. On the other hand, women may be less likely to move because they are often the primary caregivers of their children, and sole custodial parents are expected to move less often. Cooke, Mulder, and Thomas (2016) observe that, among parents, those with resident children are less likely to migrate than those without, while the latter are just as likely to migrate as nonparents. Recent research indicates that women move out of the joint home more often than men but not if they have children (Mulder and Wagner 2010; Dewilde 2008; Gram-Hanssen and Bech-Danielsen 2008; Thomas, Mulder, and Cooke 2017). These results are also found in France (Villaume 2016). 
Hypothesis 3: We expect the gender gap in observed changes in residence following divorce to be moderated by sole custodial status, but not by shared or no custody arrangements.

\subsection{Consequences of the move}

Beyond changes in residence, the question of spatial trajectories has also gained importance in the literature (Feijten and van Ham 2007). Researchers are interested not only in who moves but also in where people move to (in terms of distance and the type of environment), as well as in the type of housing adjustments made.

\subsubsection{The distance of the move}

When parents want to maintain a constant relationship with their children, they may wish to move close to where the children live. Moving far from the preseparation joint home is generally associated with higher costs, both monetary (e.g., it is more expensive to see the children after moving further away) and nonmonetary (e.g., there is an increased risk of losing contact with children and friends). Parents will move closer to the preseparation home than nonparents will (Mulder and Malmberg 2011; Cooke, Mulder, and Thomas 2016). Gram-Hanssen and Bech-Danielsen (2008) show that separated parents live closer to each other than childless people do. Cooke, Mulder, and Thomas (2016) observe that parents' postseparation migration decisions are highly correlated, unlike those of childless ex-couples.

With regard to custodial status, a recent study by Thomas, Mulder, and Cooke shows that "the distance between separated parents is almost three times shorter when both have a child(ren) resident as compared to when only the mother has the shared child(ren)" (2017: 11). Along the same lines, Stjernström and Strömgren (2012) observe that distances between children and their absent parents have decreased over time in Sweden. They link this trend to the increasingly common practice of shared custody arrangements following separation, which reflects changing norms and values concerning parenthood.

Thus, we expect that the more equally time with the children is shared, the closer the parents will live to each other, because their child custody arrangements will involve frequent visits and journeys to school.

Hypothesis 4: Parents with shared custody are expected to move less far away after separation than parents with sole custody. 


\subsubsection{Housing conditions}

As the literature has demonstrated, divorce often leads to a "downward move on the housing ladder," especially for women (Mikolai and Kulu 2018b). This downward move is exemplified by an exit from homeownership (Dewilde 2008), which in Britain is twice as likely for separated men and women as for couples (Mikolai and Kulu 2018b). However, the same study also shows gender differences. After separation, women are more likely than men to move out of the joint home and more likely to apply for social housing, especially when they are mothers, whereas men are more likely to become homeowners. Further, the general worsening of the housing situation on separation is also marked by a move to a smaller residence (Mikolai and Kulu 2018a). Since men are more likely to continue living in the joint home, they are less likely to suffer from a decline in housing conditions. However, moving out strongly depends on the presence of children and on child custody arrangements. Previous studies (Mikolai and Kulu 2018a) in the British context found that parents are less likely than childless people to move to smaller homes.

A larger property is necessary for the custodial parent because the child(ren) will live with them, but a smaller one may be sufficient for the noncustodial parent. In cases of shared custody, two properties of a similar size may be needed, though this will mean giving up other expenses for parents with a limited budget.

Hypothesis 5: We expect the decline in housing quality to be less pronounced in cases of both sole and shared custody than in cases of noncustody.

\section{The French context}

Marriage rates in France have halved since the beginning of the 1970s, while cohabitation has become common. The civil union called PACS was introduced in 1999 and is now widespread as a form of legal union (Mazuy et al. 2014). Compared with marriage, a PACS is simpler to enter into and to dissolve. It has also become similar in terms of taxation, ${ }^{5}$ although it offers less protection in matters such as inheritance ${ }^{6}$ and survivor's pensions (in the case of a partner's death). The legal framework for cohabiting couples is less protective. ${ }^{7}$

${ }^{5}$ As of 2005, all PACS partners are required to file joint tax returns, as married couples do. Because income taxation is progressive, filing jointly rather than separately leads to paying less tax in almost all cases where one partner earns substantially more than the other.

${ }^{6}$ Partners do not inherit from each other unless it is stipulated in a will.

${ }^{7}$ Joint taxation is not possible and cohabiting partners are not eligible for a survivor's pension. 
Separation and divorce are widespread in France. In 2014, 44 divorces were recorded for every 100 marriages, and PACS dissolutions increased over the period 2010-2013. In 2012, 52\% of divorces involved a child who was a minor (HCF 2014).

Until recently, divorce required the intervention of a family court judge. The average duration of divorce proceedings depends on agreement between the divorcees on all the legal and economic aspects of dissolution (home, alimony, child custody arrangements, etc.). Uncontested divorce is rapid and takes 3.6 months $^{8}$ on average, while more acrimonious divorces last longer, on average 27.8 months (French Ministry of Justice 2016).

Court decisions mandate parental custody arrangements, child support payments, and the distribution of property and goods. The decision about child custody might be exactly what is proposed by the parents, who are often advised by their lawyers. In most cases, they come to an agreement before the judgement. Agreement about the property depends on occupancy arrangements. If renting, the partner who leaves the joint home is obliged to keep paying his or her part of the rent until the divorce is finalized. If both parents have equal ownership, the partner who stays in the joint home normally has to buy the other partner's share. If both partners leave and sell the property, they are in general both entitled to half of the sale price. Special cases are ruled on specifically by the judge.

With a few exceptions, legal custody, which gives parents the right to decide about the well-being of their child (e.g., health and education), is shared, but physical custody is granted exclusively to the mother in the majority of cases (70\% of divorces in 2012) (Carrasco and Dufour 2015). Shared custody is granted in about one-fifth of cases (21\%), while sole custody to fathers accounts for $6 \%$. In the French context, shared custody means roughly that the child's time is divided equally between each parent. Parents are also expected to share child-related costs equally. In cases of sole custody, the visiting rights of the noncustodial partner and the amount of child support to be paid are decided by the judge.

With regard to housing tenure, $58 \%$ of households were owner-occupiers of their main residence in 2013 (Laferrère, Pouliquen, and Rougerie 2017), while the remainder rented in either the private or the public (social) housing sectors. Social housing in France provides accommodation at moderate rents to low-income households. Since the early 2000s, the public administration's objective has been to reach a $20 \%$ share of social housing in the total housing provision of each municipality. Due to their low income, single-parent families are overrepresented in social housing (Trevien 2014).

\footnotetext{
${ }^{8}$ Since January 2017, the duration of an uncontested divorce has been further reduced and, as long as all parties meet the deadline, couples can now divorce in less than a month.
} 


\section{Data, methods, and variables}

\subsection{Data and sample}

To answer our research questions, we use the French Permanent Demographic Sample (Echantillon démographique permanent or EDP), an administrative database linking censuses, vital events registration, and salaries for individuals born in the first four days of January, April, July, and October of each year ("EDP-individuals"). Since 2010, this database has also been linked to the entire tax-declaring French population. The strength of this data relative to panel or retrospective surveys is the large sample size, the lack of attrition even in cases of moving, and the available information on shared custody arrangements.

The analytical sample consists of 21,290 heterosexual divorced people or people who have dissolved their civil unions (about 2.3\% of unions) in 2011 or 2012 and were tracked over at least three consecutive fiscal years. Because of missing values for some of the control variables (especially on income), the empirical analyses were performed on 20,099 observations (9,968 men and 10,131 women). The observation window begins in the year before separation, when people are still married or in a civil union and have filed a joint income tax return. The data provides information on their income and current accommodation, as well as on several individual and household characteristics. In the year of union dissolution $(t)$, they declare themselves as either "divorced" or "living single" (the latter applies to the PACS) or state that separation was their last conjugal event. Finally, one year after separation $(t+1)$ and for half of the sample at two years $(t+2)$, we study information on their current situation (Table 1). The data allows tracking of EDP-individuals. ${ }^{10}$ We gather information on other family members, should there be any, if they are coresident. However, after a divorce or a PACS dissolution, we can no longer identify the partners of EDP-individuals ${ }^{11}$ (if they are not EDP-individuals themselves) because they have left the household.

\footnotetext{
${ }^{9}$ In cases of multiple tax returns for the same individual (frequent in cases of separation), we prioritized the one with the earliest change in residence.

${ }^{10}$ These people are unique because we can link their information from censuses, vital events registrations, and tax returns, while being able to follow them over time.

${ }^{11}$ This would be feasible for a very small portion of the sample (about $0.2 \%$ ): in other words, couples comprising two EDP-individuals who were both born on the selected dates of the panel inclusion criteria.
} 


\section{Table 1: Dataset description}

\begin{tabular}{llll}
\hline $\mathbf{T}-\mathbf{1}$ (in couple, shared housing) & $\begin{array}{l}\mathbf{T} \text { (year of divorce or } \\
\text { civil union dissolution) }\end{array}$ & $\begin{array}{l}\mathbf{T}+\mathbf{1} \text { (housing change, } \\
\text { location, conditions) }\end{array}$ & Sample size \\
\hline 2010 & 2011 & 2012 & 10,608 \\
2011 & 2012 & 2013 & 10,682 \\
\hline
\end{tabular}

Source: French Permanent Demographic Sample (INSEE), 2010-2013

\subsection{Methods}

Because the previous literature has shown that moves after divorce are likely to be gendered (see Section 2.2), we estimate models for the entire sample and separately by sex. Control variables for child custody arrangements are observed for parents only. Therefore, for each sex (and outcome category) we estimate two models: for the whole sample and for parents only.

Different models are estimated according to the nature of the outcome variable. Logistic regressions are used to model both the probability of moving ( $Y=1$ when people change accommodation the year after divorce, $Y=0$ otherwise) and the probability of experiencing worse housing conditions $(Y=1$ if moving from owneroccupier to renter, $Y=0$ otherwise; $Y=1$ if moving to fewer bedrooms per person, $Y=0$ otherwise; and $Y=1$ if moving to a smaller property per person, $Y=0$ otherwise).

To analyse the distance of the move, we estimate a multinomial logistic regression on whether they move short ( $Y=1$ if same municipality), medium $(Y=2$ if same county), or long ( $Y=3$ if outside county) distances. We then use linear regressions on the distance of the move measured in kilometres. This alternative indicator of continuous distance is more accurate. Indeed, there might be cases in which two municipalities are very close but belong to two different counties.

We are fully aware that child custody arrangements and mobility choices are decided simultaneously and are interrelated. Therefore, we use an instrumental variable to correct for this possible endogeneity due to possible reverse causality or unobserved characteristics (the results are provided in Appendix Table A-5). We expect endogeneity to be particularly significant as regards the distance moved following divorce, but we have made this correction on the other outcomes considered (decision to move and housing conditions). In our instrumental variable approach, we take advantage of the huge territorial discrepancies in shared custody arrangements at the regional level in France (Bonnet, Garbinti, and Solaz 2015). We thus use shared custody at the county level (France is comprised of around 100 county-like administrative divisions called départements) as an instrument for individual shared custody arrangements. The share of child custody ranges from $7 \%$ to $21 \%$ depending on the place of residence. Reasons for this may include the effect of the decisions of a 
divorce court (or a family court judge) at the local level. We checked for other possible explanations linked to local variations, such as socioeconomic situation or religiosity, but no obvious external causes explain this rate, confirming that it is a reliable instrument because it is randomly defined from the individual's point of view. The high value of the F-statistics in the first-stage regression guards against the risk of a weak instrument.

\subsection{Variables}

\subsubsection{Outcomes}

We studied three dimensions of mobility: the probability of the move itself, its distance, and the housing conditions following the move. First, we calculate the probability of moving: that is, whether in the year following the divorce the EDP-individual lives in the same accommodation as before the divorce. Then, for movers, we studied the location of residence after divorce: whether the ex-partners live in the same municipality as before, not in the same municipality but in the same county, or beyond, that is to say outside the county of residence before divorce.

We also took into account the distance in kilometres between the two locations. For this we used a software application called Metric, developed by INSEE (Bigard, Timotéo, and Levy 2014), which calculates the direct-route distance between two municipalities. ${ }^{12}$

To measure housing conditions after divorce, we used several indicators: the type of housing tenure (homeownership, private or public renting), the number of bedrooms per person, and the size of the home per person in square metres. Exit from ownership is another indicator of worse living conditions. The literature considers ownership to be a desirable goal, and the well-being of a household is assumed to be greater when one is an owner (Spilerman and Wolff 2012). Homeownership is also usually associated with a wide range of beneficial outcomes (Dewilde 2008).

\subsubsection{Variables of interest}

Our variables of interest are parenthood status (parents or childless) at the moment of divorce and, for the subsample of divorced parents, the child custody arrangements after

\footnotetext{
${ }^{12}$ For overseas territories, we decided to take the maximum distance of the move, imputed differently by sex and parenthood status. For people in Corsica, we took the distance between Marseille and the Corsican town plus the distance between the town in metropolitan France and Marseille.
} 
divorce. ${ }^{13}$ Thus, we distinguish between parents with sole, shared, or no child custody. Type of child custody is associated with different income tax deductions and is thus reported on tax returns. ${ }^{14}$ The custody arrangement is self-declared, and the proportion of shared custody declared by fathers is greater than that of mothers, who have more tax incentives to declare sole custody. ${ }^{15}$ Beyond tax optimization reasons, parents are more likely to declare their children even if they do not live with them full-time, as shown by Toulemon, Durier, and Marteau (2017).

\subsubsection{Controls}

We controlled for a set of sociodemographic variables (see Appendix Table A-1): sex; age at divorce $(20-29,30-39,40-49,50-59,60$ and over); age gap between partners (whether the man is older, both are the same age, or the woman is older); age of the youngest child (less than 3 years, 4-14 years, 15 years or more); duration of marriage (less than 4 years, 4-6 years, $7-10$ years, more than 10 years or unknown duration ${ }^{16}$ ); number of children; and nationality (native or foreign-born). With respect to socioeconomic covariates, we considered two dimensions, education (divided into four groups: lower than secondary, secondary, higher than secondary, or missing ${ }^{17}$ ) and adjusted household income (grouped by quintiles). This is the sum of all employmentrelated incomes (including unemployment or retirement benefits) received by the two partners, divided by the number of consumption units, using the OECD-modified equivalence scale that gives 1 for adults, 0.3 for children under 14, and 0.5 for children 14 and over or for other adults in the household. We also considered, as an additional indicator of poverty, whether any household member received unemployment benefits during the year before divorce. Such a situation could exacerbate housing difficulties in a high-demand housing market and therefore hinder residential mobility. However, the

\footnotetext{
${ }^{13}$ Again we use the term 'divorce,' but we consider both marriage and PACS dissolutions. Duties and rights of parents do not change, regardless of their conjugal status.

${ }^{14}$ Tax deductions are higher for parents with sole custody than for those with shared custody, where tax deductions are shared.

${ }^{15}$ Parents with no custody also include parents whose child moves elsewhere to another fiscal household: e.g., if he or she becomes a student and files a separate tax return.

${ }^{16}$ Dates of marriages and civil unions are available from those that took place after 2000, so we assume that unknown dates refer those that occurred before. We could not exclude the possibility that a few dates are missing for other reasons.

${ }^{17}$ Educational level is retrieved from the census, which is conducted on a rotating subsample of the French resident population every five years. As the level of education is assumed to be quite stable over time, we consider information on education each time the individual identified from fiscal data is found in the census. However, the linkage was possible on only $63 \%$ of the total sample; the remainder was assumed to be missing.
} 
unemployed might also be less constrained than the employed in their choices about place of residence, thus making them more spatially mobile.

We further controlled for housing tenure before divorce by distinguishing between owner-occupiers, those with public and private rented accommodation, and, as a proxy for location-specific capital, time spent in the predivorce home: fewer than 5 years, 5-9 years, and 10 years or more. Furthermore, we separated rural areas from cities categorized as small (up to 20,000 inhabitants), medium (up to 200,000), and large (up to 2 million inhabitants), and the Paris area. Finally, we took into account whether the individual was married or in a civil union.

\section{Results}

\subsection{Descriptive statistics}

Divorce involves a change of residence for at least one partner and sometimes for both. We omit the special cases of so-called LTA (living together apart) couples, who continue to cohabit after divorce or separation for, say, financial reasons. This has been shown to be uncommon (Martin, Cherlin, and Cross-Barnet 2011) and would concern only $5 \%$ of divorced couples in the year immediately following divorce (Durier 2017).

Table 2 shows the distribution of the outcome variables for the entire sample and the subsample of parents by sex. We find that fewer men move after divorce $-59 \%$ of men compared with $67 \%$ of women - which is consistent with the literature.

For parents, this gender gap is narrower, with $61 \%$ of men and $66 \%$ of women moving, while it is larger for the childless, with $56 \%$ of men and $71 \%$ of women. This means that parental status (and probably the custodial status, as women are much more likely to be given custody) moderates the gender gap in the likelihood of moving, as predicted by Hypothesis 3 .

When divorcees move, they relocate within the same municipality $(29 \%)$ or even outside it but within the same county (47\%). The mean distance is around 79 kilometres, but the median remains low (18 kilometres). Therefore, consistent with Hypothesis 1, parents do not move as far away from the preseparation home as nonparents, and are more likely to move within the municipality. Moving outside the county relates to one in five parents and more than $30 \%$ of childless ex-partners, who have fewer reasons than parents to remain close to the joint home. 
Ferrari, Bonnet \& Solaz: Residential mobility after divorce by parenthood status and custody arrangements

Table 2: Observed outcome frequency distributions and descriptive statistics, by sex and parenthood status (column percentages)

\begin{tabular}{|c|c|c|c|c|c|c|c|}
\hline \multirow[b]{2}{*}{ A year after divorce } & \multirow[b]{2}{*}{ Total } & \multicolumn{2}{|c|}{ All } & \multicolumn{2}{|c|}{ Childless } & \multicolumn{2}{|c|}{ Parent } \\
\hline & & Men & Women & Men & Women & Men & Women \\
\hline \multicolumn{8}{|l|}{ Do they move? } \\
\hline No & 37 & 41 & 33 & 44 & 29 & 39 & 34 \\
\hline Yes & 63 & 59 & 67 & 56 & 71 & 61 & 66 \\
\hline Total & 100 & 100 & 100 & 100 & 100 & 100 & 100 \\
\hline \multirow[t]{2}{*}{$\mathrm{N}$} & 21,290 & 10,512 & 10,778 & 3,298 & 3,344 & 7,214 & 7,434 \\
\hline & \multicolumn{7}{|c|}{ For movers only } \\
\hline \multicolumn{8}{|l|}{ Where do they move? } \\
\hline Same municipality & 29 & 28 & 30 & 23 & 27 & 29 & 32 \\
\hline Same county & 47 & 48 & 47 & 44 & 43 & 50 & 49 \\
\hline Different county & 24 & 24 & 23 & 33 & 30 & 21 & 19 \\
\hline Total & 100 & 100 & 100 & 100 & 100 & 100 & 100 \\
\hline $\begin{array}{l}\text { Mean distance (kilometres) } \\
\text { Total }\end{array}$ & 79 & 80 & 78 & 113 & 106 & 66 & 64 \\
\hline $\begin{array}{l}\text { Median distance (kilometres) } \\
\text { Total }\end{array}$ & 18 & 19 & 17 & 26 & 23 & 17 & 15 \\
\hline $\mathrm{N}$ & 13,491 & 6,241 & 7,250 & 1,845 & 2,363 & 4,396 & 4,887 \\
\hline \multicolumn{8}{|l|}{$\begin{array}{l}\text { What changes in housing } \\
\text { conditions? }\end{array}$} \\
\hline Fewer bedrooms & 52 & 54 & 50 & 46 & 52 & 57 & 49 \\
\hline Same number of bedrooms & 25 & 24 & 27 & 25 & 23 & 23 & 29 \\
\hline Fewer bedrooms per person & 31 & 29 & 32 & 36 & 33 & 26 & 32 \\
\hline $\begin{array}{l}\text { Same number of bedrooms } \\
\text { per person }\end{array}$ & 15 & 13 & 16 & 18 & 19 & 11 & 15 \\
\hline Smaller size & 67 & 67 & 67 & 59 & 66 & 70 & 68 \\
\hline Smaller size per person & 34 & 30 & 38 & 39 & 36 & 27 & 39 \\
\hline \multirow[t]{2}{*}{$\underline{N}$} & 13,491 & 6,241 & 7,250 & 1,845 & 2,363 & 4,397 & 4,889 \\
\hline & \multicolumn{7}{|c|}{ For movers and owner-occupiers only } \\
\hline Owner-occupier to owner & 31 & 35 & 29 & 41 & 34 & 33 & 26 \\
\hline $\begin{array}{l}\text { Owner-occupier to private } \\
\text { renter }\end{array}$ & 55 & 55 & 55 & 50 & 52 & 57 & 57 \\
\hline $\begin{array}{l}\text { Owner-occupier to public } \\
\text { renter }\end{array}$ & 14 & 10 & 16 & 9 & 14 & 10 & 17 \\
\hline Total & 100 & 100 & 100 & 100 & 100 & 100 & 100 \\
\hline $\mathrm{N}$ & 7,719 & 3,444 & 4,275 & 889 & 1,189 & 2,555 & 3,086 \\
\hline
\end{tabular}

Source: French Permanent Demographic Sample (INSEE), 2010-2013.

The new home does not necessarily have fewer bedrooms: around half do, while a quarter have a similar number and the remaining quarter have even more bedrooms than the previous property. Fathers who move are the most likely to live in a new home with fewer bedrooms $(57 \%)$. One reason might be that they have custody of the child less often. Though in most cases the property is smaller, it is not necessarily smaller relative to the new household configuration after divorce. In other words, the reduction in property size might be in line with the new household size. Among parents, mothers are more affected by a reduction in their living area per person: $39 \%$ have less space per 
person after divorce than before, compared with $27 \%$ of fathers. In contrast, among childless divorcees, $39 \%$ of men and $36 \%$ of women have less space per person in their new home. For childless people, particularly women, the housing is often smaller and with fewer bedrooms, but it does not always involve a reduction per person, as they benefit from the whole space if they live alone.

Among spouses who were owner-occupiers of their housing (59\%), a substantial proportion $(69 \%)$ became tenants in either the private or the public sector within the year following divorce. ${ }^{18}$ Parents, and particularly women, are more likely to 'lose' their status of owner-occupier than childless divorcees. In most cases, they become private tenants. Parents and women become public tenants more frequently than childless people and men. In $17 \%$ of cases, mothers who were previously owners move into public housing. Having fewer financial resources after separation is the main reason for this. Given the difficulties and the time required to obtain social housing in France, these rates are remarkable as they are observed right after the transition. They suggest that there is a real desire to help divorced mothers and their children (Trevien 2014).

\subsection{Multivariate analysis}

\subsubsection{Moving after divorce}

Table 3 shows the results of the logistic regressions separately for the full sample and for parents only, by sex.

In the full model, women are more likely to move than men. This result is in line with the relative resources argument: because men are on average older than women and earn higher wages in the labour market, their economic resources are also higher on average, and they are more likely than women to have accumulated wealth at the moment of divorce. Their higher income may allow them to keep a home that is familysized, whereas women have fewer resources, especially if they took time off from their jobs to have children.

\footnotetext{
${ }^{18}$ Our data does not show whether the joint house or flat belongs to both spouses or to only one. In most cases, however, married couples are joint owners of their main residence. According to Bonnet, Keogh, and Rapoport (2014), 84\% of homes are equally and jointly owned by married spouses.
} 
Ferrari, Bonnet \& Solaz: Residential mobility after divorce by parenthood status and custody arrangements

Table 3: Logit models of moving out of the joint home one year after divorce, by sex (odds ratios)

\begin{tabular}{|c|c|c|c|c|c|}
\hline & \multirow{2}{*}{ All } & \multicolumn{2}{|c|}{ Men } & \multicolumn{2}{|c|}{ Women } \\
\hline & & All & Parents & All & Parents \\
\hline \multicolumn{6}{|c|}{ Parenthood (Ref: childless) } \\
\hline Parent & $1.27^{\star \star \star}$ & $1.42^{\star \star \star}$ & & $0.70^{\star \star \star}$ & \\
\hline \multicolumn{6}{|l|}{ Sex (Ref: man) } \\
\hline Woman & $1.90^{\star \star \star}$ & & & & \\
\hline Woman*Parent & $0.60^{\star \star \star}$ & & & & \\
\hline \multicolumn{6}{|c|}{ Child custody arrangement } \\
\hline Sole custody & & & $0.41^{* \star *}$ & & Ref. \\
\hline Shared custody & & & $0.39^{* \star *}$ & & $2.90^{\star \star *}$ \\
\hline No custody & & & Ref. & & $2.55^{\star \star \star}$ \\
\hline \multicolumn{6}{|c|}{ Number of children (Ref: 1 child) } \\
\hline 2 children & & & $1.30^{* \star *}$ & & $0.86^{\star *}$ \\
\hline 3 or more children & & & $1.25^{\star \star \star}$ & & $0.69^{\star \star \star}$ \\
\hline \multicolumn{6}{|c|}{ Age of the youngest child (Ref: $0-3$ ) } \\
\hline 4-14 & & & $0.83^{* *}$ & & 0.91 \\
\hline $15+$ & & & $0.79^{\star \star}$ & & $0.67^{\star \star \star}$ \\
\hline \multicolumn{6}{|l|}{ Age at divorce (Ref: 30-39) } \\
\hline $20-29$ & $1.40^{\star \star \star}$ & $1.32^{* * \star}$ & 1.20 & $1.35^{\star \star \star}$ & 1.14 \\
\hline $40-49$ & $0.72^{\star \star \star}$ & $0.81^{\star \star *}$ & $0.83^{\star *}$ & $0.73^{\star \star \star}$ & $0.74^{\star \star \star}$ \\
\hline 50-59 & $0.59^{\star \star \star}$ & $0.77^{\star * \star}$ & $0.74^{\star \star \star}$ & $0.57^{\star \star \star}$ & $0.56^{\star \star \star}$ \\
\hline $60+$ & $0.58^{\star \star \star}$ & $0.85^{*}$ & $0.62^{\star \star}$ & $0.50^{\star \star \star}$ & $0.38^{\star *}$ \\
\hline \multicolumn{6}{|c|}{ Age difference between the partners (Ref: same age $+/-4$ years) } \\
\hline Man older & $0.91^{\star \star \star}$ & $0.64^{\star \star *}$ & $0.67^{* \star \star}$ & $1.25^{\star \star \star}$ & $1.26^{* \star *}$ \\
\hline Woman older & 0.91 & $1.49^{* * *}$ & $1.73^{\star \star \star}$ & $0.61^{* \star \star}$ & $0.58^{* \star *}$ \\
\hline \multicolumn{6}{|c|}{ Level of education (Ref: lower than secondary) } \\
\hline Secondary & 0.95 & 0.95 & 0.93 & $0.88^{*}$ & 0.89 \\
\hline Higher than secondary & $0.91^{* *}$ & 1.00 & 1.09 & $0.79^{* \star \star}$ & $0.74^{\star \star \star}$ \\
\hline Not available & $1.25^{\star \star \star}$ & $1.34^{* \star *}$ & $1.47^{\star \star \star}$ & 1.08 & 1.08 \\
\hline \multicolumn{6}{|c|}{ Adjusted household income quintiles (Ref: Q3: $€ 18,347-22,665$ ) } \\
\hline Q1: Up to $€ 13,951$ & $0.83^{*}$ & $0.79^{* * *}$ & $0.70^{\star \star \star}$ & $0.87^{* \star}$ & 1.06 \\
\hline Q2: €13,952-18,346 & $0.91^{\star \star \star *}$ & $0.88^{*}$ & $0.79^{\star \star \star}$ & 0.93 & 1.03 \\
\hline Q4: €22,666-29,653 & $1.14^{\star *}$ & 1.10 & 1.04 & $1.18^{* *}$ & 1.07 \\
\hline Q5: More than $€ 29,654$ & $1.11^{\star \star \star}$ & 1.08 & 0.93 & 1.11 & 1.03 \\
\hline \multicolumn{6}{|c|}{ House occupancy status (Ref: owner-occupier) } \\
\hline Private renting & $1.48^{\star \star \star}$ & $1.75^{\star \star \star}$ & $1.81^{* \star *}$ & $1.23^{\star \star \star}$ & 1.08 \\
\hline Public renting & $0.74^{\star \star \star}$ & $1.16^{* *}$ & $1.33^{\star \star \star}$ & $0.49^{\star \star *}$ & $0.39^{\star \star \star}$ \\
\hline \multicolumn{6}{|c|}{ Household member receiving unemployment benefits (Ref: no) } \\
\hline Yes & 1.06 & $1.09^{*}$ & $1.13^{*}$ & 1.05 & 1.06 \\
\hline \multicolumn{6}{|c|}{ Union duration (Ref: less than 4 years) } \\
\hline $4-6$ years & 1.04 & 1.05 & 1.06 & 1.01 & 0.92 \\
\hline $7-10$ years & 1.04 & 1.00 & 0.96 & 1.06 & 0.95 \\
\hline Longer duration/unknown & $1.17^{\star \star \star}$ & $1.17^{\star \star}$ & $1.19^{*}$ & 1.07 & 0.97 \\
\hline \multicolumn{6}{|l|}{ Nationality (Ref: native) } \\
\hline Foreign-born & $0.90^{* *}$ & $0.89^{*}$ & 0.89 & $0.83^{\star \star *}$ & $0.82^{* *}$ \\
\hline
\end{tabular}


Table 3: (Continued)

\begin{tabular}{|c|c|c|c|c|c|}
\hline & \multirow{2}{*}{ All } & \multicolumn{2}{|c|}{ Men } & \multicolumn{2}{|c|}{ Women } \\
\hline & & All & Parents & All & Parents \\
\hline \multicolumn{6}{|c|}{ Town size (Ref: $200,000-1,999,999$ inhabitants) } \\
\hline Rural & 1.04 & $0.80^{* \star *}$ & $0.79^{* * *}$ & $1.37^{* * *}$ & $1.51^{\star \star \star}$ \\
\hline $2,000-19,999$ inhabitants & $1.13^{\star *}$ & 0.97 & 1.04 & $1.33^{\star \star \star}$ & $1.46^{\star \star \star}$ \\
\hline $20,000-199,999$ inhabitants & 1.05 & 1.06 & 1.03 & 1.05 & $1.16^{\star}$ \\
\hline Paris area & $0.78^{\star \star \star}$ & $0.86^{\star \star}$ & 0.92 & $0.75^{\star \star *}$ & $0.79^{* \star *}$ \\
\hline \multicolumn{6}{|c|}{ Time spent in the accommodation (Ref: more than 10 years) } \\
\hline$<5$ years & $1.32^{\star * *}$ & $1.51^{\star \star *}$ & $1.58^{* \star *}$ & $1.27^{\star \star *}$ & $1.26^{\star \star \star}$ \\
\hline $5-9$ years & $1.13^{\star \star *}$ & $1.25^{\star \star *}$ & $1.42^{* \star *}$ & 1.09 & 1.00 \\
\hline \multicolumn{6}{|l|}{ Type of union (Ref: marriage) } \\
\hline Civil union & $0.89^{* *}$ & $0.84^{\star \star}$ & 0.89 & 1.00 & 1.00 \\
\hline Constant & $1.17^{*}$ & 0.90 & $1.78^{\star \star \star}$ & $2.72^{\star \star *}$ & $2.13^{\star \star \star}$ \\
\hline Observations & & 9,968 & 6,503 & 10,131 & 6,638 \\
\hline
\end{tabular}

Note: ${ }^{* \star *} p<0.01,{ }^{* *} p<0.05,{ }^{*} p<0.1$

Source: French Permanent Demographic Sample (INSEE), 2010-2013

Parenthood positively affects residential mobility (first column of Table 3). However, an interesting opposite effect of parenthood is observed by sex: fathers are more likely than childless men to move out of the joint home, whereas mothers are less likely than childless women to do so. These results are probably linked to both the parental desire not to change the child's environment (Mulder and Wagner 2010) and the custody arrangements. This suggests that the mother, who is more likely to be the custodial parent, will stay with the children in the original joint home whenever possible, which is in line with Hypothesis 2. As shown by the regression on only parents, which controls for the custody arrangements (third and fifth columns), regardless of sex, the parent who has sole custody is indeed less likely to move than a noncustodial parent. ${ }^{19}$ The predicted probabilities of custody arrangements (computed on the full model that accounts for the interaction between sex and custody arrangements) clearly confirm that sole custodial parents are less likely to move (50\% for men, $60 \%$ for women) than noncustodial parents ( $70 \%$ or more). This is emphasized by the increasing probability of moving for fathers with more than one child, but shows a decreasing probability for mothers with several children. The joint home is kept for the children and the sole custodial parent, probably to avoid relocating the children. This may be reinforced by the family court judge, who may more often decide to grant custody to the parent who keeps the house in "the best interests of the child." The story differs in shared custody arrangements. Here, fathers are much less likely to move

\footnotetext{
${ }^{19}$ Note that the reference category differs for the male and female regressions because we prefer to refer to the most frequent situation by sex: no custody for the fathers and sole custody for the mothers. However, predicted probabilities for the three types of custody are also computed (Figure 1).
} 
(under 50\%) than mothers (over 80\%). ${ }^{20}$ Because the children in shared custody may remain (even if only part of the time) with either the father or the mother in the original joint home, this is in line with our third hypothesis, since the issue of not moving the children no longer plays a role in deciding who keeps the joint home. The greater relative resources of fathers compared with mothers may therefore lead to their being more likely to keep the joint home.

\section{Figure 1: Predicted probabilities of moving one year after divorce, by sex and child's custody arrangements}

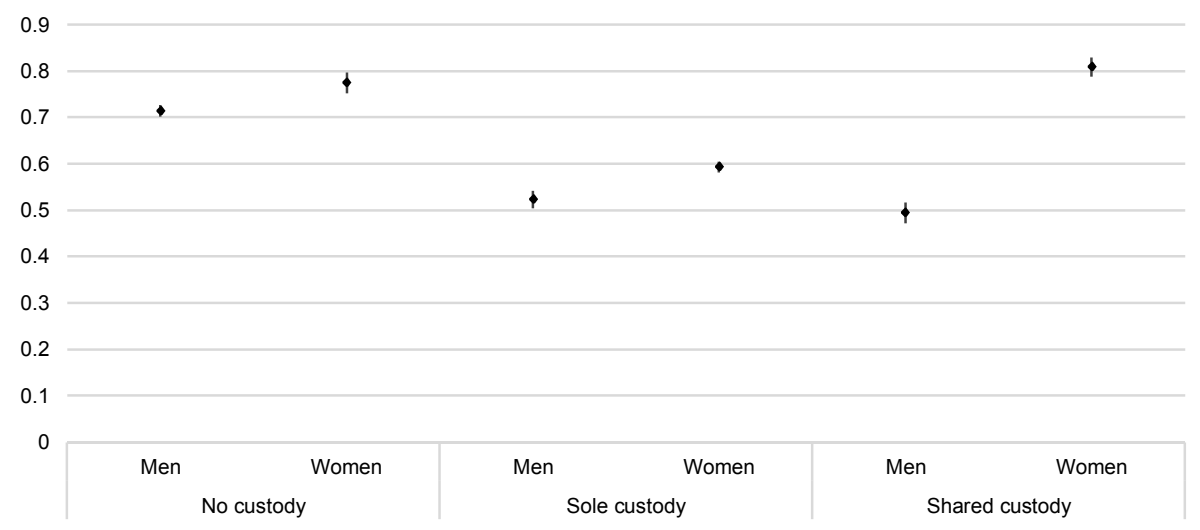

Note: Whiskers represent $95 \%$ confidence intervals.

Source: French Permanent Demographic Sample (INSEE), 2010-2013

Regarding the other covariates, we find that the probability of moving after divorce decreases with age. The age gap plays a role too, with the older spouse less likely to move, while the younger one is more likely. This difference may be due to the negotiation process between the couple or to wealth accumulation. The older spouse may be the one who was already living in the joint home when the couple got together or the one who has accumulated more wealth. The probability of moving also decreases with the age of the youngest child, because moving is easier before children are enrolled in school. The educational gradient is small: that is, not significant for men's moves and negative for women's. However, we observe an income gradient. Men and women belonging to low adjusted income quintiles are less likely to move than those

${ }^{20}$ Our data does not allow for analysis of some atypical arrangements, such as when the children stay in the joint home and the parents move in and out. 
belonging to the median quintile. It might be that, for financial reasons, disadvantaged families move less or take longer to move.

Ownership status reduces mobility for men, while residing in the public and private rental sector increases it. In contrast, renting in the public sector reduces the chances of moving for women, especially for mothers who might keep the joint home. In the same vein, when a family member has received unemployment benefits, it increases the likelihood of moving for men. We also find that marriage duration has no effect and that foreign-born status has a small negative effect on mobility for women. People living in the Paris area are less likely to move, probably because of the high cost of housing, which may prolong the search for a suitable place. We observe a gendered result for living in a rural area. While men are less likely to move out of the joint home, we find the opposite for women. This could be related to the fact that men more often choose the couple's place of residence or are likely to have initially owned it for professional reasons, such as farming, or other reasons related to wealth. In these cases, women would be the ones to leave the premises.

\subsubsection{Moving distance}

Shorter moving distances are observed for parents. Fathers and mothers are more likely to move nearby in the same municipality than childless men and women (see Appendix Table $\mathrm{A}-2^{21}$ ) and less likely to move far. When fathers move, they live 32 kilometres closer to their former homes than childless divorced men, while mothers live 22 kilometres closer than childless divorced women (see Appendix Table A-3). These results are in line with Hypothesis 1, probably in order to maintain contact with the children. If parents have sole custody, they often keep the original joint home (Figure 2). Figure 2 also shows that shared custody arrangements limit parents' relocation. The predicted probability of fathers with shared custody living in the original joint home reaches $50 \%$, and $20 \%$ move into a new home while remaining in the same predivorce municipality. While mothers in shared custody are more likely to move than lone mothers or fathers in sole custody, they generally move closer to the joint home. Family court judges probably take into account the distance between parents (among other reasons) when deciding to accept or reject a shared custody arrangement. The probability of parents with shared custody moving beyond the county borders is low (less than $5 \%$ for fathers and less than $10 \%$ for mothers), while this may happen more frequently with the sole custodial parent. Parents with sole custody have a $12 \%$ probability of living outside the predivorce county in the year following divorce, whereas the probability of leaving the original municipality while remaining in the

${ }^{21}$ Because multinomial logistic coefficients are not easy to interpret we show average marginal effects. 
same county exceeds $25 \%$ for both fathers and mothers. Shared custody involves moving a 37-kilometre shorter distance for men and a 78-kilometre shorter distance for women, relative to non-custodial parents. For women, shared custody involves moving a 55-kilometre shorter distance relative to those who have sole custody. This is in line with our fourth hypothesis: that is, shared custody arrangements are associated with shorter moves than other types of custody following divorce.

Figure 2: Predicted probabilities of not moving, moving within the same municipality, moving within the same county, or beyond one year after divorce, by sex and child custody arrangements

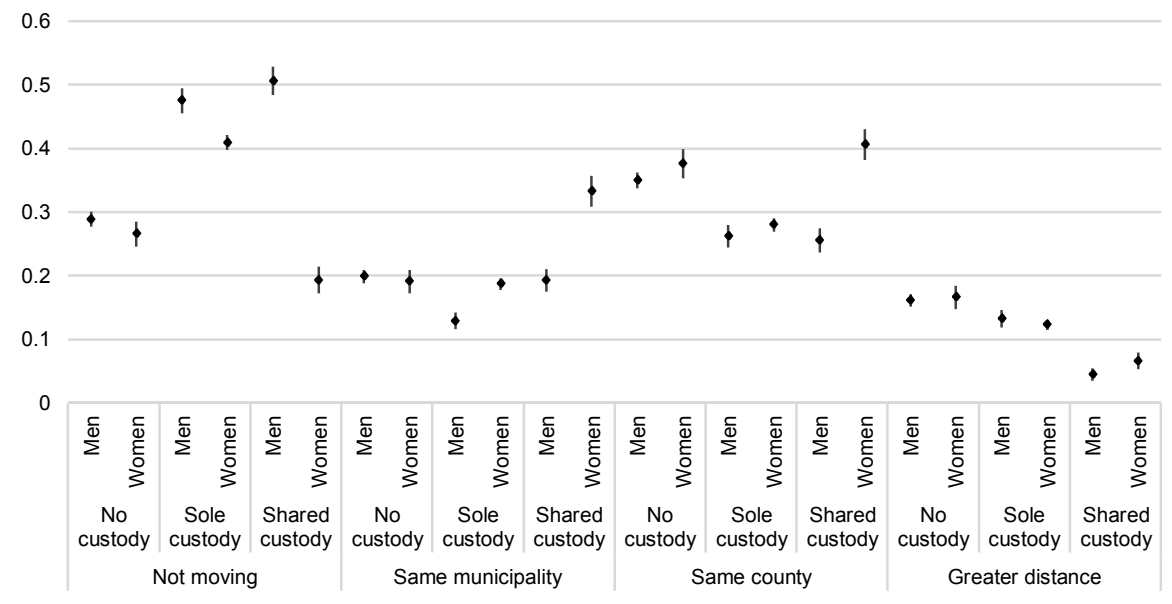

Note: Whiskers represent $95 \%$ confidence intervals.

Source: French Permanent Demographic Sample (INSEE), 2010-2013

\subsubsection{Housing conditions}

Finally, we looked at the decline in housing quality. To study whether conditions deteriorate following separation, we combined different indicators of housing quality. First, we examined the risk of stopping being a homeowner one year after divorce (Table 4). Parental status is not associated with a higher probability of stopping homeownership during the first year after separation. For fathers, having sole custodial status is associated with a greater chance of remaining a homeowner. There is no difference by custodial status for women. Women are more likely to lose their owneroccupier status after divorce. This may be related to their comparatively worse financial 
situation, which limits their ability to move and keep their ownership status. The decision whether to sell the joint home is not particularly associated with custodial status.

Table 4: Logit models of moving out of homeownership for the subsample of movers one year after divorce, by sex (odds ratios)

\begin{tabular}{|c|c|c|c|c|c|}
\hline & \multirow{2}{*}{ All } & \multicolumn{2}{|c|}{ Men } & \multicolumn{2}{|c|}{ Women } \\
\hline & & All & Parents & All & Parents \\
\hline \multicolumn{6}{|c|}{ Parenthood (Ref: childless) } \\
\hline Parent & 1.15 & 1.17 & & 1.14 & \\
\hline \multicolumn{6}{|l|}{ Sex (Ref: man) } \\
\hline Woman & $1.26^{\star *}$ & & & & \\
\hline Woman ${ }^{\star}$ Parent & 1.02 & & & & \\
\hline \multicolumn{6}{|c|}{ Child custody arrangement (Ref: no custody) } \\
\hline Sole custody & & & $0.76^{\star *}$ & & Ref. \\
\hline Shared custody & & & 1.07 & & 0.97 \\
\hline No custody & & & Ref. & & 0.93 \\
\hline \multicolumn{6}{|c|}{ Number of children (Ref: 1 child) } \\
\hline 2 children & & & 1.00 & & 0.95 \\
\hline 3 or more children & & & $1.14^{*}$ & & $0.97^{* * *}$ \\
\hline \multicolumn{6}{|c|}{ Age of the youngest child (Ref: $0-3$ ) } \\
\hline $4-14$ & & & 0.85 & & 0.83 \\
\hline $15+$ & & & $0.72^{*}$ & & $0.51^{* * *}$ \\
\hline \multicolumn{6}{|c|}{ Age at divorce (Ref: 30-39) } \\
\hline $20-29$ & 0.93 & 1.22 & 0.92 & 0.79 & 0.88 \\
\hline $40-49$ & $0.78^{* \star *}$ & $0.79^{\star *}$ & 0.81 & $0.77^{\star \star *}$ & 0.87 \\
\hline $50-59$ & $0.65^{\star \star *}$ & $0.71^{\star * *}$ & 0.74 & $0.59^{\star * *}$ & 0.72 \\
\hline $60+$ & $0.47^{* * *}$ & $0.49^{* \star *}$ & 0.68 & $0.46^{\star * *}$ & 1.55 \\
\hline \multicolumn{6}{|c|}{ Age difference between the partners (Ref: same age $+/-4$ years) } \\
\hline Man older & 1.04 & 0.96 & 0.97 & 1.12 & 1.02 \\
\hline Woman older & 1.09 & 1.06 & 1.11 & 1.13 & 1.07 \\
\hline \multicolumn{6}{|c|}{ Level of education (Ref: lower than secondary) } \\
\hline Secondary & $0.80^{* \star}$ & 0.89 & 0.99 & $0.73^{\star \star *}$ & $0.68^{* *}$ \\
\hline Higher than secondary & $0.67^{* * *}$ & $0.77^{* *}$ & 0.82 & $0.59^{\star * *}$ & $0.52^{* * *}$ \\
\hline Not available & $0.77^{* * *}$ & $0.79^{* *}$ & 0.81 & $0.75^{\star \star \star}$ & $0.69^{\star \star \star}$ \\
\hline \multicolumn{6}{|c|}{ Adjusted household income quintiles (Ref: Q3: $€ 18,347-22,665$ ) } \\
\hline Q1: Up to $€ 13,951$ & $1.25^{\star \star}$ & 1.09 & 1.19 & $1.40^{\star *}$ & 1.30 \\
\hline Q2: €13,952-18,346 & $1.27^{\star \star *}$ & 1.19 & 1.09 & $1.32^{\star \star}$ & $1.33^{*}$ \\
\hline Q4: €22,666-29,653 & $0.84^{\star \star}$ & 0.98 & 1.01 & $0.72^{\star * *}$ & $0.67^{\star \star \star}$ \\
\hline Q5: More than $€ 29,654$ & $0.73^{\star \star *}$ & $0.76^{* *}$ & $0.72^{* *}$ & $0.69^{* * *}$ & $0.64^{* \star *}$ \\
\hline \multicolumn{6}{|c|}{ Household member receiving unemployment benefits (Ref: no) } \\
\hline Yes & 1.03 & 1.00 & 1.03 & 1.07 & 1.05 \\
\hline
\end{tabular}


Table 4: (Continued)

\begin{tabular}{|c|c|c|c|c|c|}
\hline & \multirow{2}{*}{ All } & \multicolumn{2}{|c|}{ Men } & \multicolumn{2}{|c|}{ Women } \\
\hline & & All & Parents & All & Parents \\
\hline \multicolumn{6}{|c|}{ Union duration (Ref: less than 4 years) } \\
\hline $4-6$ years & 1.05 & 1.21 & 1.27 & 0.94 & 0.96 \\
\hline $7-10$ years & 1.00 & 1.13 & 1.05 & 0.92 & 0.98 \\
\hline Longer duration/unknown & 1.04 & 1.15 & 1.12 & 0.97 & 1.20 \\
\hline \multicolumn{6}{|l|}{ Nationality (Ref: native) } \\
\hline Foreign-born & $1.25^{\star *}$ & $1.33^{\star *}$ & $1.40^{\star}$ & 1.17 & 1.20 \\
\hline \multicolumn{6}{|c|}{ Town size (Ref: 200,000-1,999,999 inhabitants) } \\
\hline Rural & 0.99 & 0.96 & 1.05 & 1.02 & 0.88 \\
\hline $2,000-19,999$ inhabitants & 1.00 & 1.00 & 1.19 & 1.02 & 0.83 \\
\hline $20,000-199,999$ inhabitants & 0.91 & 0.90 & 0.91 & 0.94 & 0.84 \\
\hline Paris area & $0.83^{* *}$ & 0.95 & 1.00 & $0.72^{* *}$ & $0.54^{\star * \star}$ \\
\hline \multicolumn{6}{|c|}{ Time spent in the accommodation (Ref: more than 10 years) } \\
\hline$<5$ years & $1.17^{* *}$ & $1.20^{*}$ & 1.19 & $1.19^{*}$ & $1.30^{* *}$ \\
\hline $5-9$ years & 1.04 & 1.12 & 1.12 & 1.00 & 1.09 \\
\hline \multicolumn{6}{|l|}{ Type of union (Ref: marriage) } \\
\hline Civil union & 0.89 & 0.81 & 0.77 & 0.96 & 0.99 \\
\hline Constant & $2.68^{* * *}$ & $2.13^{\star \star \star}$ & $2.66^{\star \star \star}$ & $4.12^{\star \star \star}$ & $6.42^{\star \star \star}$ \\
\hline Observations & 7,381 & 3,321 & 2,274 & 4,060 & 2,763 \\
\hline
\end{tabular}

Note: ${ }^{* * *} p<0.01,{ }^{* *} p<0.05,{ }^{*} p<0.1$.

Source: French Permanent Demographic Sample (INSEE), 2010-2013

Second, we analysed the probability of living in a smaller property after divorce (see Appendix Table A-4). We define a smaller property as a reduction in the number of bedrooms or the space per person. Family size is thus taken into account.

Fathers do not seem to experience a greater reduction in the number of bedrooms or the space per person than childless divorcees do after their separation. On the contrary, mothers are more likely to have a smaller property than childless divorcees, in terms of both number of bedrooms and space per person. Hence, fathers are less likely to suffer a decline in their living standards after divorce than mothers. However, the results of the model on parents (that only controls for child custody arrangements) mitigate the relative advantage of fathers, since fathers who have custody are also penalized. After divorce, they are more likely to live in housing that is smaller per person. Figure 3 shows that parents who have custody, either sole or shared, are more likely to have fewer bedrooms per person than parents whose children live elsewhere. Thus, the decline in housing conditions after divorce is more pronounced for mothers and for custodial parents in general. Our fifth hypothesis, which suggests a less marked decline in housing quality in custody versus noncustody cases, is therefore not fully supported by the data. 
Figure 3: Predicted probabilities of moving to accommodation with fewer bedrooms per person one year after divorce, by sex and child custody arrangements

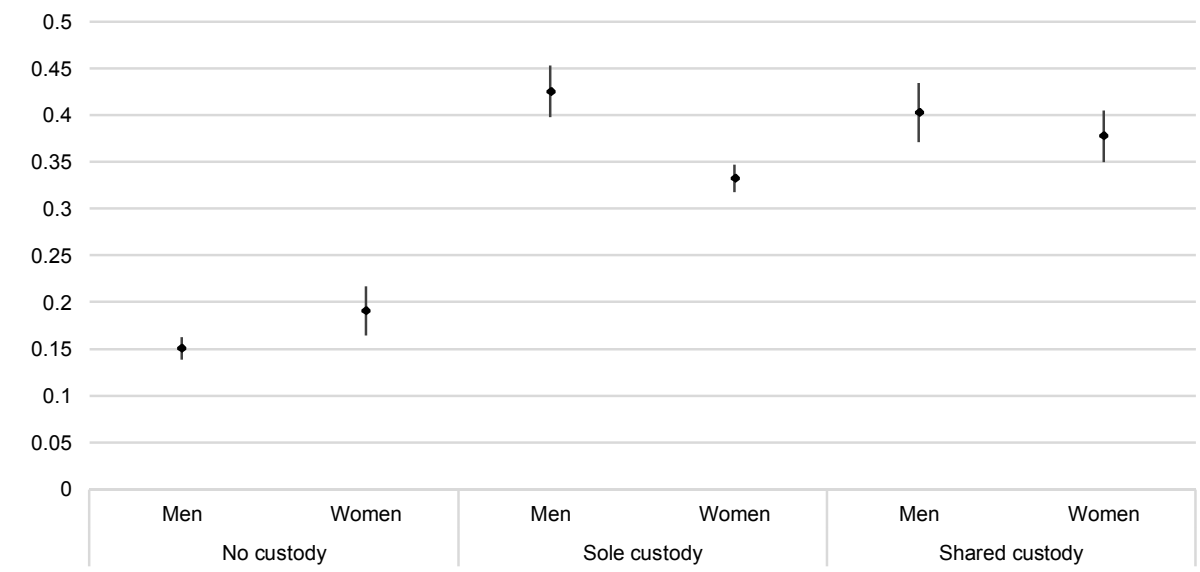

Note: Whiskers represent $95 \%$ confidence intervals.

Source: French Permanent Demographic Sample (INSEE), 2010-2013

\subsection{Endogeneity issues}

Custody arrangements and housing may be decided simultaneously. To tackle this endogeneity issue, we tested the robustness of our results using an instrumental variable approach. We took the proportion of shared custody at the county level as an instrument. Table A-5 presents the main results. The sign and the significance of the coefficients are very similar when using the instrumented custody arrangements regarding the probability of moving, distance of the move, and housing conditions. This means that, once endogeneity issues are taken into account, our results hold.

\section{Discussion and conclusions}

Although the economic and psychological consequences of divorce for both adults and children have been widely investigated, housing outcomes of divorced individuals have been less well studied, mainly because of the scarcity of adequate data for observing residential changes around the time of divorce. Using recently available administrative 
data which allows French divorcees to be tracked, we observed their mobility and the changes in their housing characteristics after divorce. We focused on parental status and postdivorce child custody arrangements.

Consistent with previous research and the relative resources argument that emphasizes the role of bargaining power between partners, our empirical findings show that women are more likely to move than men after divorce. In most cases, men have higher earnings than women, and this could explain why they are more likely to keep the joint home. But parenthood status mitigates the gender gap, which is narrower for parents. Mothers move less frequently than childless women, while fathers move more than childless men. Furthermore, we show that moving behaviour is related to the type of custody. For both sexes, sole custodial status is associated with less moving than is the case with noncustodial status, which may reflect a preference for not moving the child(ren) from the joint home, at least shortly after divorce. However, shared custody arrangements imply many more moves for mothers than for fathers. Parents move nearby in cases of shared custody. The willingness to maintain relationships with the child and his or her environment certainly plays a role. Yet these additional spatial constraints may have implications for other aspects of life, such as job market opportunities, chances of repartnering, relationships with the family of origin, and, more broadly, participation in the housing market. The increased demand for shared custody can imply a greater number of moves for women and may affect housing prices and demand for certain types of homes (e.g., houses and flats with two or three bedrooms).

Housing characteristics are not necessarily worse after divorce, but women are more often disadvantaged. They are more likely to lose their owner-occupier status and to have less space in their new home. The alternative of remaining would not necessarily be better if they are unable to afford the whole cost of the joint (and often oversized) home. This result corroborates previous findings on the greater negative consequences of divorce for women than for men. Gender inequality in the consequences of divorce, in terms of mobility and housing characteristics, may also be of interest for public policy. There is now a debate in France about whether housing allowances could be shared in cases of shared custody. The current policy allows for only one parent to receive a housing allowance; the recipient is usually the mother because she received other benefits from social security before the divorce, such as family allowances. Thus, in shared custody arrangements, generally only the mother receives a housing allowance, even if the father faces additional housing costs to accommodate the children. A solution would be to share housing allowances. The objective of the policymaker is to make benefits available to both parents if a child spends significant time with them (Meyer and Carlson 2014; HCF 2014). The sharing of housing allowances may be in line with this policy, as it helps parents share 
economic and childcare costs. It may be desirable to support families (perhaps fathers in particular) in their efforts to maintain postseparation proximity (when desired), as this will facilitate their postseparation well-being.

This work has some limitations. First, the fiscal data that we used allowed us to study only married people and civil partners, as they are the ones who filed joint income tax returns. People who left cohabiting unions are thus excluded from our analysis. We might expect to have similar results for cohabitating parents because they have similar characteristics in France and their rights are comparable to those of married (and PACSed) parents in terms of the children (Prioux 2009). Although it is not compulsory for unmarried and PACSed parents, in most cases they go to a family court judge, who decides on child custody and alimony. However, they enjoy fewer protections than married people when the union dissolves. In contrast to divorce, no spousal alimony is provided in cases of unequal resources between partners. However, based on our different indicators for moving and housing characteristics, our results show few differences between PACSed and married parents, suggesting that the results are likely to be similar for cohabitating parents. Further research is necessary to confirm this expectation.

Second, we observed the housing situation only one year after divorce. Although the literature indicates that mobility is greater just following divorce, there may be a later adjustment in housing conditions, in particular if the relocation was to nonoptimal accommodation. Nevertheless, Villaume (2016) used a larger observation window of up to four years to observe mobility after separation and found similar results regarding parenthood status for women, although they were slightly different for fathers. She found no distinction in the probability of moving by fatherhood status, whereas we show that fatherhood has a positive effect on the probability of moving. This could mean that it takes more time for childless men to move than it does for fathers. Some of the changes in status from owner to renter may be only temporary because buying a new home takes longer. With the next round of data (available soon), we intend to extend the observation window after divorce.

Third, we can observe the postdivorce location of only one of the partners and so cannot link the postdivorce locations of both partners, which may be of interest, particularly for parents.

Fourth, as previously mentioned, child custody arrangements are not completely exogenous and stable over time; they might change in the years following divorce (Cretin 2015).

Nevertheless, our analysis has shed light on a previously understudied phenomenon and shown that postdivorce childcare arrangements and residential choices are related. It opens opportunities for further research to analyse postdivorce mobility over the long term within a context of changing coparenting norms and behaviours. 


\section{Acknowledgements}

This work was funded by the French National Research Agency (grant ANR-16-CE410007-01). We are grateful to the two anonymous reviewers and the guest editors for their invaluable suggestions that significantly improved the paper. We also thank Christopher Leichtnam for his careful language editing. In addition, we thank participants at the research and policy symposium at St Andrews (UK) in May 2017, as well as those who attended the 15th Meeting of the European Network for the Sociological and Demographic Study of Divorce in Antwerp (Belgium) in October 2017, particularly for their comments and remarks. 


\section{References}

Amato, P.R. (2001). Children of divorce in the 1990s: An update of the Amato and Keith (1991) meta-analysis. Journal of Family Psychology 15(3): 355-370. doi:10.1037/0893-3200.15.3.355.

Amato, P.R. (2010). Research on divorce: Continuing trends and new developments. Journal of Marriage and Family 72(3): 650-666. doi:10.1111/j.1741-3737. 2010.00723.x.

Andreß, H.-J. and Bröckel, M. (2007). Income and life satisfaction after marital disruption in Germany. Journal of Marriage and Family 69(2): 500-512. doi:10.1111/j.1741-3737.2007.00379.x.

Bigard, M., Timotéo, J., and Levy, D. (2014). Guide d'utilisation du distancier METRIC [electronic resource]. Paris: Archives de Données Issues de la Statistique Publique. http://www.progedo-adisp.fr/documents/MEDIAS/Guide_ distancier.pdf.

Bonnet, C., Garbinti, B., and Solaz, A. (2015). Les conditions de vie des enfants après le divorce. Paris: Insee (Insee Première 1536).

Bonnet, C., Garbinti, B., and Solaz, A. (2016). Gender inequality after divorce: The flip side of marital specialization: Evidence from a French administrative database. Paris: Insee (Document de travail G2016-03).

Bonnet, C., Keogh, A., and Rapoport, B. (2014). Quels facteurs pour expliquer les écarts de patrimoine entre hommes et femmes en France? Economie et Statistique 472-473: 101-123. doi:10.3406/estat.2014.10491.

Bonvalet, C. (1993). Le logement et l'habitat dans les trajectoires familiales. Revue des Politiques Sociales et Familiales 31(1): 19-37.

Cancian, M., Meyer, D., Brown, P., and Cook, S. (2014). Who gets custody now? Dramatic changes in children's living arrangements after divorce. Demography 51(4): 1381-1396. doi:10.1007/s13524-014-0307-8.

Carrasco, V. and Dufour, C. (2015). Les décisions des juges concernant les enfants de parents séparés ont fortement évolué dans les années 2000. Paris: French Ministry of Justice (Infostat Justice 132).

Cooke, T.J., Mulder, C.H., and Thomas, M. (2016). Union dissolution and migration. Demographic Research 34(26): 741-760. doi:10.4054/DemRes.2016.34.26. 
Ferrari, Bonnet \& Solaz: Residential mobility after divorce by parenthood status and custody arrangements

Cretin, L. (2015). Résidence et pension alimentaire des enfants de parents séparés: Décisions initiales et évolutions. In: Insee (ed.). Insee références: Couples et familles. Paris: Insee: 41-50.

Dewilde, C. (2008). Divorce and the housing movements of owner-occupiers: A European comparison. Housing Studies 23(6): 809-832. doi:10.1080/026730308 02423151 .

Durier, S. (2017). Après une rupture d'union, l'homme reste plus souvent dans le logement conjugal. Paris: Insee (Insee Focus 91).

Feijten, P. and Van Ham, M. (2007). Residential mobility and migration of the divorced and separated. Demographic Research 17(21): 623-653. doi:10.4054/DemRes. 2007.17.21.

Festy, P. (1988). Statut d'occupation du dernier domicile conjugal et mobilité résidentielle à partir de la separation. In: Transformation de la famille et habitat. Paris: INED: 95-106.

French Ministry of Justice (2016). Les affaires familiales [electronic resource]. Paris: French Ministry of Justice. http://www.justice.gouv.fr/art_pix/Stat_Annuaire ministere-justice_2016_chapitre1.pdf.

Gram-Hanssen, K. and Bech-Danielsen, C. (2008). Home dissolution: What happens after separation? Housing Studies 23(3): 507-522. doi:10.1080/0267303080 2020635.

Hango, D.W. (2006). The long-term effect of childhood residential mobility on educational attainment. The Sociological Quarterly 47(4): 631-664. doi:10.1111/j.1533-8525.2006.00061.x.

Hetherington, E.M. (2003). Social support and the adjustment of children in divorced and remarried families. Childhood 10(2): 217-236. doi:10.1177/0907568203 010002007.

HCF - Haut Conseil de la Famille (2014). Les ruptures familiales: Etats des lieux et propositions [electronic resource]. Paris: HCF. http://www.hcfea.fr/IMG/pdf/ 2014_04_LES_RUPTURES_FAMILIALES.pdf.

Laferrère, A., Pouliquen, E., and Rougerie, C. (2017). Les conditions de logement en France. Paris: Insee.

Lyngstad, T.H. and Jalovaara, M. (2010). A review of the antecedents of union dissolution. Demographic Research 23(10): 257-292. doi:10.4054/DemRes. 2010.23.10. 
Martin, C., Cherlin, A., and Cross-Barnet, C. (2011). Living together apart: Vivre ensemble séparés: Une comparaison France-États-Unis. Population 66(3): 647669. doi:10.3917/popu.1103.0647.

Mazuy, M., Barbieri, M., d'Albis, H., and Reeve, P. (2014). Recent demographic trends in France: The number of marriages continues to decrease. Population 69(3): 273-321.

Meyer, D.R. and Carlson, M.J. (2014). Family complexity: Implications for policy and research. Annals of the American Academy of Political and Social Science 654(1): 259-276. doi:10.1177/0002716214531385.

Mikolai, J. and Kulu, H. (2018a). Divorce, separation, and housing changes: A multiprocess analysis of longitudinal data from England and Wales. Demography 55(1): 83-106. doi:10.1080/00324728.2017.1391955.

Mikolai, J. and Kulu, H. (2018b). Short- and long-term effects of divorce and separation on housing tenure in England and Wales. Population Studies 72(1): 17-39. doi:10.1080/00324728.2017.1391955.

Mulder, C.H. and Malmberg, G. (2011). Moving related to separation: Who moves and to what distance. Environment and Planning A 43(11): 2589-2607. doi:10.1068/ a43609.

Mulder, C.H. and Wagner, M. (2010). Union dissolution and mobility: Who moves from the family home after separation? Journal of Marriage and Family 72(5): 1263-1273. doi:10.1111/j.1741-3737.2010.00763.x.

Mulder, C.H., Ten Hengel, B., Latten, J., and Das, M. (2012). Relative resources and moving from the joint home around divorce. Journal of Housing and the Built Environment 27(2): 153-168. doi:10.1007/s10901-011-9250-9.

Prioux, F. (2009). Les couples non mariés en 2005: Quelles différences avec les couples mariés? Politiques sociales et familiales 96: 87-95.

Spilerman, S. and Wolff, F.C. (2012). Parental wealth and resource transfers: How they matter in France for home-ownership and living standards. Social Science Research 41(2): 207-223. doi:10.1016/j.ssresearch.2011.08.002.

Stjernström, O. and Strömgren, M. (2012). Geographical distance between children and absent parents in separated families. Geografiska Annaler: Series B, Human Geography 94(3): 239-253. doi:10.1111/j.1468-0467.2012.00412.x.

Sullivan, O. (1986). Housing movements of the divorced and separated. Housing Studies 1(1): 35-48. doi:10.1080/02673038608720561. 
Symon, P. (1990). Housing and divorce. Glasgow: University of Glasgow.

Thomas, M., Mulder, C.H., and Cooke, T.-J. (2017). Geographical distances between separated parents: A longitudinal analysis. European Journal of Population 34(4): 463-489. doi:10.1007/s10680-017-9437-1.

Toulemon, L., Durier, S., and Marteau, B. (2017). Two homes, two families? People counted twice in the French rotating census. Paper presented at the XXVIII International Population Conference, Cape Town, South Africa, October 29November 3, 2017.

Trevien, C. (2014). Habiter en HLM: Quel avantage monétaire et quel impact sur les conditions de logement? Économie et Statistiques 471: 33-64. doi:10.3406/ estat.2014.10480.

Villaume, S. (2016). Naissances, séparations et changements de logement. Revue Française des Affaires Sociales 3: 29-64.

Wolfinger, N.H. (1999). Trends in the intergenerational transmission of divorce. Demography 33: 415-420. doi:10.2307/2648064. 


\section{Appendix}

Table A-1: Descriptive statistics of variables used in the analyses

\begin{tabular}{|c|c|c|c|c|c|c|c|c|c|c|c|c|c|c|c|}
\hline & \multirow{2}{*}{$\mathbf{N}$} & \multicolumn{3}{|c|}{$\%$ in sample } & \multicolumn{3}{|c|}{$\%$ moved } & & \multirow{2}{*}{$\mathbf{N}$} & \multicolumn{4}{|c|}{$\%$ in sample } & \multicolumn{2}{|c|}{$\%$ moved } \\
\hline & & All & Men & Wome & n All & Men & Women & & & All & Men & Wome & n All & Men & Women \\
\hline \multicolumn{8}{|l|}{ Parenthood } & \multicolumn{8}{|c|}{ Equalized household income (quintiles) } \\
\hline Childless & 6,642 & 31.2 & 31.4 & 31.0 & 31.2 & 29.6 & 32.6 & $\begin{array}{l}\text { Q1: Up to } \\
€ 13,951\end{array}$ & 4,032 & 20.0 & 19.2 & 20.8 & 19.0 & 18.6 & 19.4 \\
\hline Parents & 14,648 & 68.8 & 68.6 & 69.0 & 68.8 & 70.4 & 67.4 & $\begin{array}{l}\text { Q2: €13,952- } \\
18,346\end{array}$ & 4,035 & 20.0 & 19.9 & 20.1 & 19.7 & 19.7 & 19.7 \\
\hline \multicolumn{8}{|c|}{ Number of children } & $\begin{array}{l}\text { Q3: €18,347- } \\
22,665\end{array}$ & 4,031 & 20.0 & 19.8 & 20.2 & 20.3 & 20.0 & 20.5 \\
\hline 1 child & 5,215 & 35.6 & 35.1 & 36.1 & 35.9 & 34.4 & 37.2 & $\begin{array}{l}\text { Q4: €22,666- } \\
29,653\end{array}$ & 4,034 & 20.0 & 20.5 & 19.6 & 20.9 & 21.0 & 20.8 \\
\hline 2 children & 6,274 & 42.8 & 43.6 & 42.1 & 43.6 & 44.4 & 42.8 & $\begin{array}{l}\text { Q5: €29,654- } \\
1,060,559\end{array}$ & 4,031 & 20.0 & 20.7 & 19.3 & 20.1 & 20.6 & 19.7 \\
\hline 3 or more children & 3,159 & 21.6 & 21.3 & 21.8 & 20.6 & 21.2 & 20.1 & \multicolumn{8}{|c|}{ House occupancy status } \\
\hline \multicolumn{8}{|c|}{ Child custody arrangement } & Owner & 12,525 & 58.8 & 59.8 & 57.9 & 57.2 & 55.2 & 59.0 \\
\hline No custody & 5,305 & 36.2 & 55.4 & 17.6 & 39.5 & 62.7 & 18.6 & Private renting & 5,367 & 25.2 & 24.8 & 25.6 & 29.0 & 29.5 & 28.6 \\
\hline Sole custody & 6,897 & 47.1 & 25.5 & 68.1 & 43.5 & 21.4 & 63.3 & Public renting & 3,398 & 16.0 & 15.4 & 16.5 & 13.8 & 15.3 & 12.4 \\
\hline Shared custody & 2,446 & 16.7 & 19.1 & 14.3 & 17.1 & 15.9 & 18.1 & \multicolumn{8}{|c|}{ Household member receiving unemployment benefits } \\
\hline \multicolumn{8}{|c|}{ Age of the youngest child } & No & 14,849 & 69.8 & 70.2 & 69.3 & 69.1 & 169.3 & 68.9 \\
\hline $0-3$ & 2,587 & 29.7 & 30.1 & 29.4 & 27.4 & 27.1 & 27.7 & Yes & 6,441 & 30.3 & 29.8 & 30.7 & 30.9 & 30.7 & 31.1 \\
\hline $4-14$ & 4,955 & 57 & 56.4 & 57.4 & 58.4 & 58.4 & 58.3 & \multicolumn{8}{|l|}{ Union duration } \\
\hline \multirow[t]{2}{*}{$15+$} & 1,158 & 13.3 & 13.5 & 13.2 & 14.2 & 14.4 & 14.0 & $0-3$ years & 3,584 & 16.8 & 16.9 & 16.8 & 17.9 & 17.6 & 18.1 \\
\hline & & & & & & & & $4-6$ years & 2,989 & 14.0 & 13.9 & 14.2 & 14.6 & 14.5 & 14.6 \\
\hline Sex & & & & & & & & $7-10$ years & 3,164 & 14.9 & 14.7 & 15.0 & 14.7 & 14.3 & 15.1 \\
\hline Man & 10,512 & 49.4 & & & 46.3 & & & $\begin{array}{l}\text { Longer } \\
\text { duration/ } \\
\text { unknown }\end{array}$ & 11,553 & 54.3 & 54.6 & 54.0 & 52.9 & 53.7 & 52.2 \\
\hline Woman & 10,778 & 50.6 & & & 53.7 & & & Nationality & & & & & & & \\
\hline Age at divorce & & & & & & & & Native & 17,995 & 84.5 & 83.8 & 85.2 & 85.5 & 84.0 & 86.9 \\
\hline $20-29$ & 1,977 & 9.3 & 6.5 & 12 & 11.3 & 8 & 14.1 & Foreign-born & 3,295 & 15.5 & 16.2 & 14.8 & 14.5 & 16.0 & 13.1 \\
\hline $30-39$ & 6,667 & 31.3 & 29.4 & 33.2 & 34.1 & 32.6 & 35.3 & Town size & & & & & & & \\
\hline $40-49$ & 7,239 & 34 & 35.5 & 32.6 & 32.5 & 34.5 & 30.7 & Rural & 4,897 & 23.4 & 23.7 & 23.1 & 23.2 & 23.1 & 25.0 \\
\hline $50-59$ & 3,800 & 17.9 & 19.7 & 16 & 15.7 & 17.4 & 14.3 & $\begin{array}{l}2,000-19,999 \\
\text { inhabitants } \\
20,000-\end{array}$ & 3,673 & 17.5 & 17.6 & 17.5 & 18.1 & 17.5 & 18.6 \\
\hline $60+$ & 1,607 & 7.6 & 8.9 & 6.2 & 6.4 & 7.4 & 5.6 & $\begin{array}{l}199,999 \\
\text { inhabitants } \\
200,000-\end{array}$ & 4,238 & 20.2 & 20.1 & 20.4 & 20.6 & 20.4 & 20.1 \\
\hline \multicolumn{8}{|c|}{ Age difference between the partners } & $\begin{array}{l}1,999,999 \\
\text { inhabitants }\end{array}$ & 5,076 & 24.2 & 24.4 & 24.1 & 24.5 & 24.1 & 23.5 \\
\hline $\begin{array}{l}\text { Man } \geq 5 \text { years } \\
\text { older }\end{array}$ & 6,165 & 29.1 & 28.9 & 29.2 & 27.9 & 24.3 & 30.9 & Paris area & 3,075 & 14.7 & 14.4 & 15.0 & 13.7 & 15.0 & 12.9 \\
\hline $\begin{array}{l}\text { Same age (+/- } 4 \\
\text { years) }\end{array}$ & 13,644 & 64.3 & 64.6 & 64.0 & 65.8 & 67.9 & 64.0 & \multicolumn{8}{|c|}{ Time spent in the accommodation } \\
\hline $\begin{array}{l}\text { Woman } \geq 5 \text { years } \\
\text { older }\end{array}$ & 1,415 & 6.7 & 6.5 & 6.8 & 6.4 & 7.8 & 5.1 & $<5$ years & 12,209 & 57.4 & 56.6 & 58.1 & 61.2 & 61.6 & 60.8 \\
\hline \multicolumn{8}{|c|}{ Level of education achieved } & $5-9$ years & 4,288 & 20.1 & 20.5 & 19.8 & 19.1 & 19.4 & 18.9 \\
\hline $\begin{array}{l}\text { Lower than } \\
\text { secondary }\end{array}$ & 6,298 & 29.6 & 32.2 & 27.0 & 28.1 & 29.5 & 26.9 & $10+$ years & 4,792 & 22.5 & 22.9 & 22.2 & 19.7 & 19.0 & 20.3 \\
\hline Secondary & 2,746 & 12.9 & 12.1 & 13.7 & 12.8 & 11.5 & 13.9 & \multicolumn{8}{|l|}{ Type of union } \\
\hline $\begin{array}{l}\text { Higher than } \\
\text { secondary }\end{array}$ & 4,435 & 20.8 & 19.2 & 22.4 & 20.7 & 18.9 & 22.3 & Marriage & 18,275 & 85.8 & 85.5 & 86.2 & 84.8 & 84.9 & 84.7 \\
\hline $\begin{array}{l}\text { Missing } \\
\text { information }\end{array}$ & 7,811 & 36.7 & 36.5 & 36.9 & 38.4 & 40.1 & 36.9 & Civil union & 3,015 & 14.2 & 14.5 & 13.8 & 15.2 & 15.1 & 15.3 \\
\hline
\end{tabular}

http://www.demographic-research.org 
Ferrari, Bonnet \& Solaz: Residential mobility after divorce by parenthood status and custody arrangements

Table A-2: Multinomial logistic regression on the probability of moving within the same municipality, same county, or beyond for the subsample of movers one year after divorce, by sex- average marginal effects

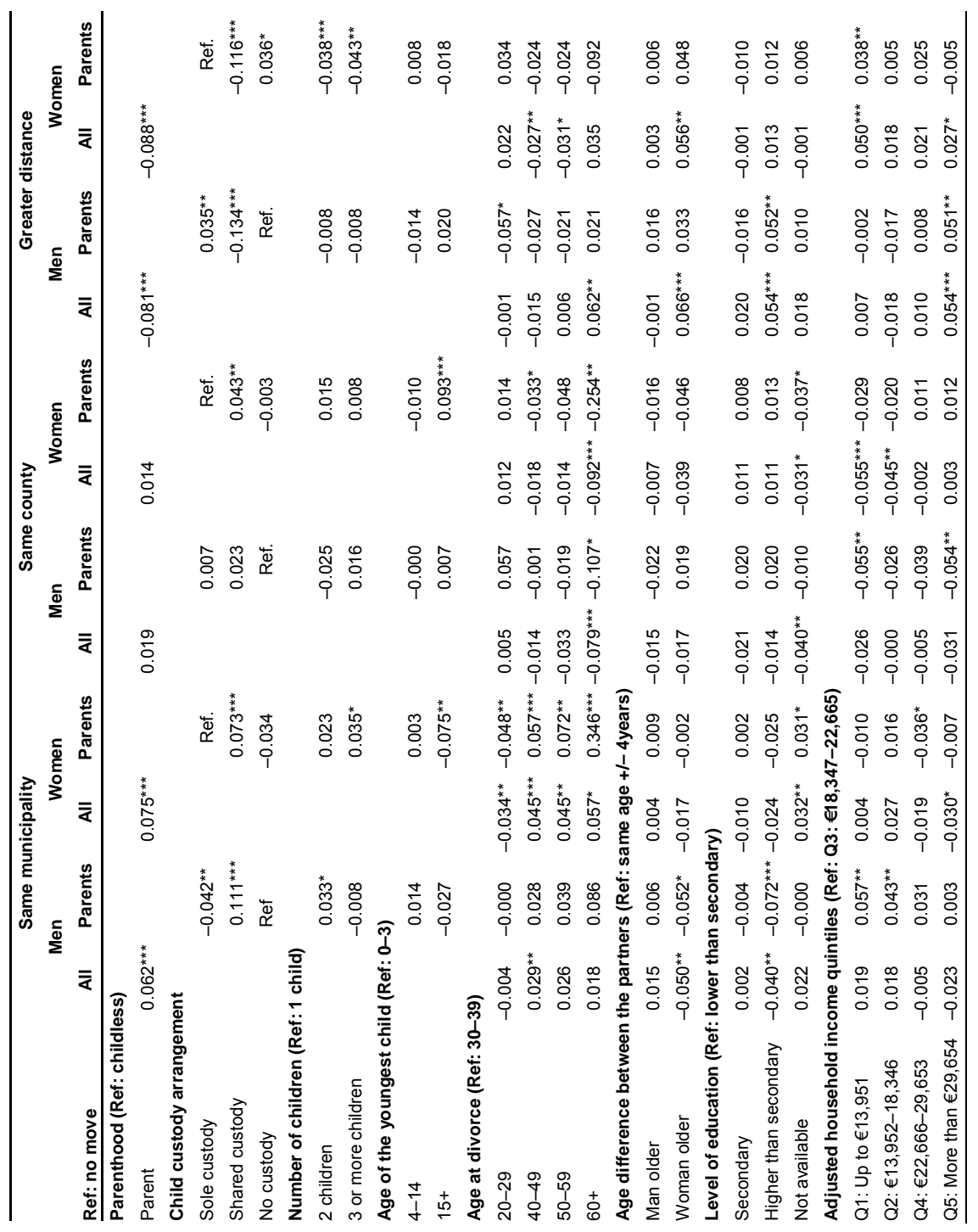


Table A-2: (Continued)

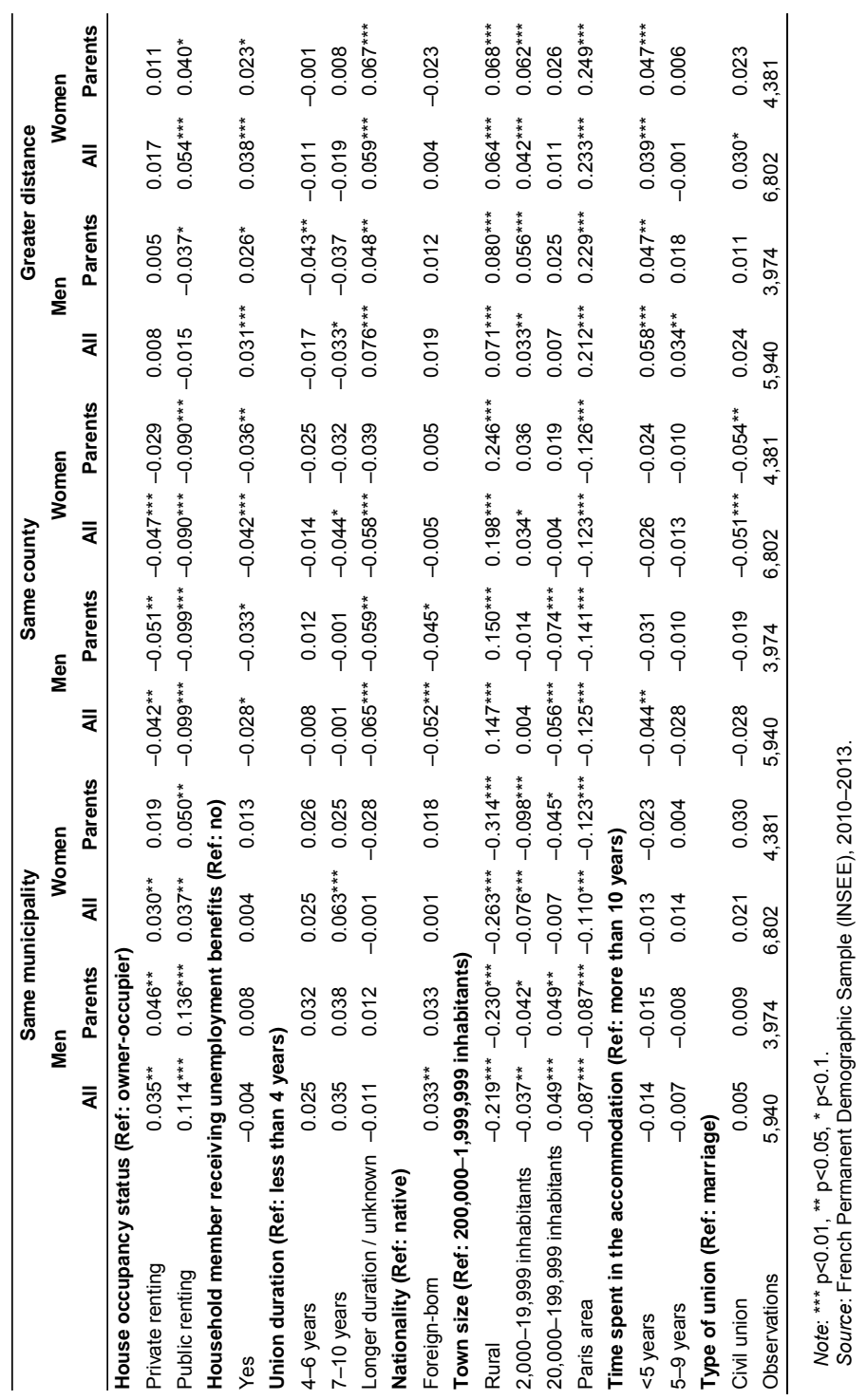


Ferrari, Bonnet \& Solaz: Residential mobility after divorce by parenthood status and custody arrangements

\section{Table A-3: Mean distance (in kilometres) between pre- and postdivorce accommodation for the subsample of movers one year after divorce, by sex (OLS regression)}

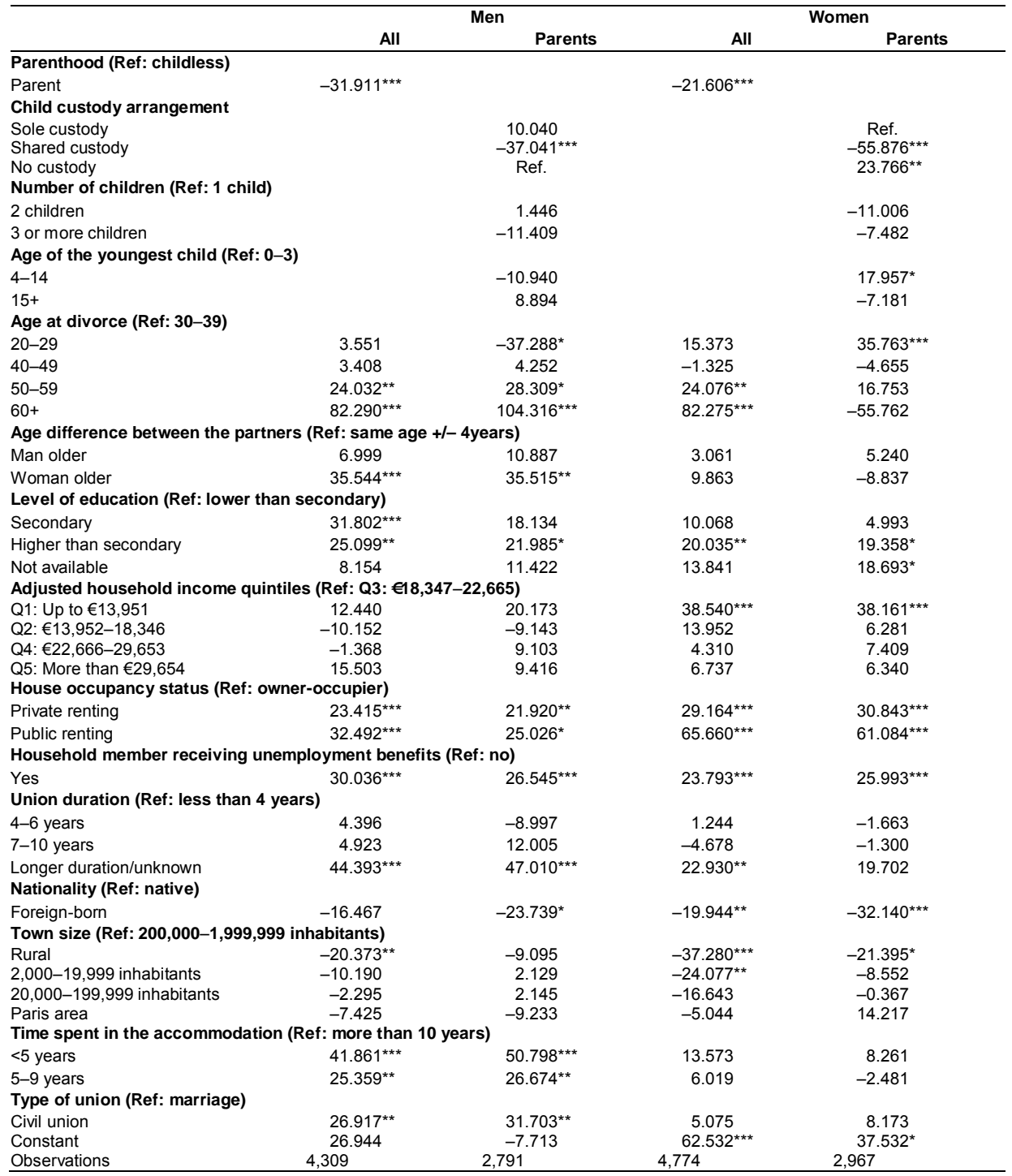

Note: ${ }^{* * *} p<0.01,{ }^{* *} p<0.05,{ }^{*} p<0.1$

Source: French Permanent Demographic Sample (INSEE), 2010-2013. 
Table A-4: Logit of moving to a smaller housing per person (fewer bedrooms/smaller size) for the subsample of movers one year after divorce, by sex (odds ratios)

\begin{tabular}{|c|c|c|c|c|c|c|c|c|c|c|}
\hline & \multicolumn{5}{|c|}{ Fewer bedrooms per person } & \multicolumn{5}{|c|}{ Less space per person } \\
\hline & \multirow{2}{*}{ All } & \multicolumn{2}{|c|}{ Men } & \multicolumn{2}{|c|}{ Women } & \multirow{2}{*}{ All } & \multicolumn{2}{|c|}{ Men } & \multicolumn{2}{|c|}{ Women } \\
\hline & & All & Parents & All & Parents & & All & Parents & All & Parents \\
\hline \multicolumn{11}{|c|}{ Parenthood (Ref: childless) } \\
\hline Parent & 1.11 & 1.10 & & $1.63^{* * *}$ & & $1.14^{*}$ & 1.13 & & $2.13^{* * *}$ & \\
\hline \multicolumn{11}{|l|}{ Sex (Ref: man) } \\
\hline Woman & $0.88^{*}$ & & & & & 0.91 & & & & \\
\hline WomanParent & $1.51^{\star \star *}$ & & & & & $1.89^{\star \star \star}$ & & & & \\
\hline \multicolumn{11}{|c|}{ Child custody arrangement } \\
\hline Sole custody & & & $5.14^{\star * *}$ & & Ref. & & & $7.28^{* \star \star}$ & & Ref. \\
\hline Shared custody & & & $4.51^{* * *}$ & & $1.18^{*}$ & & & $5.92^{* * *}$ & & 1.10 \\
\hline No custody & & & Ref. & & $0.39^{\star \star \star}$ & & & Ref. & & $0.22^{\star \star \star}$ \\
\hline \multicolumn{11}{|c|}{ Number of children (Ref: 1 child) } \\
\hline 2 children & & & 1.04 & & $1.56^{\star \star \star}$ & & & $1.30^{\star \star}$ & & $1.87^{\star \star *}$ \\
\hline 3 or more children & & & $1.41^{* \star *}$ & & $3.02^{* \star \star}$ & & & $1.61^{* \star *}$ & & $2.93^{\star \star \star}$ \\
\hline \multicolumn{11}{|c|}{ Age of the youngest child (Ref: $0-3$ ) } \\
\hline $4-14$ & & & 1.17 & & 1.01 & & & 1.04 & & 1.12 \\
\hline $15+$ & & & 1.20 & & $1.36^{*}$ & & & 1.13 & & 1.31 \\
\hline \multicolumn{11}{|c|}{ Age at divorce (Ref: $30-39$ ) } \\
\hline $20-29$ & 1.12 & 0.91 & 0.84 & $1.21^{\star \star}$ & $1.32^{\star \star}$ & 1.10 & 1.06 & 1.16 & 1.11 & $1.27^{*}$ \\
\hline $40-49$ & $0.76^{\star \star *}$ & $0.77^{* * *}$ & $0.77^{\star *}$ & $0.75^{\star \star \star}$ & $0.76^{\star \star \star}$ & $0.79^{* * *}$ & $0.83^{\star *}$ & $0.77^{\star \star}$ & $0.76^{* * *}$ & $0.80^{* *}$ \\
\hline $50-59$ & $0.50^{\star * *}$ & $0.63^{* * *}$ & $0.70^{\star *}$ & $0.38^{\star \star \star}$ & $0.59^{* \star *}$ & $0.45^{* * *}$ & $0.54^{\star \star *}$ & $0.58^{\star \star \star}$ & $0.37^{* * *}$ & $0.58^{* * *}$ \\
\hline $60+$ & $0.41^{* * *}$ & $0.48^{\star \star \star}$ & 0.97 & $0.34^{\star * *}$ & 0.40 & $0.33^{* * *}$ & $0.39^{\star \star *}$ & $0.38^{\star \star \star}$ & $0.27^{\star \star \star}$ & 0.80 \\
\hline \multicolumn{11}{|c|}{ Age difference between the partners (Ref: same age $+/-4$ years) } \\
\hline Man older & 1.04 & $0.85^{\star *}$ & 0.86 & $1.14^{\star *}$ & 1.09 & 0.99 & 0.89 & 0.98 & 1.04 & 1.01 \\
\hline Woman older & 1.13 & 0.91 & 0.85 & $1.59^{* \star *}$ & $1.58^{\star *}$ & $1.22^{\star *}$ & 1.09 & $1.39^{*}$ & $1.44^{* * *}$ & $1.44^{*}$ \\
\hline \multicolumn{11}{|c|}{ Level of education (Ref: lower than secondary) } \\
\hline Secondary & 0.91 & $0.83^{*}$ & $0.73^{* *}$ & 0.97 & 0.85 & 1.04 & 1.01 & 0.84 & 1.06 & 0.93 \\
\hline Higher than secondary & 0.93 & $0.81^{* *}$ & $0.74^{\star *}$ & 1.01 & 0.97 & 0.90 & $0.81^{* *}$ & $0.75^{\star \star}$ & 0.95 & 0.91 \\
\hline Not available & 0.98 & $0.87^{*}$ & $0.83^{*}$ & 1.09 & 1.03 & 0.95 & 0.93 & 0.93 & 0.96 & 0.93 \\
\hline \multicolumn{11}{|c|}{ Adjusted household income quintiles (Ref: Q3: €18,347-22,665) } \\
\hline Q1: Up to $€ 13,951$ & $1.13^{*}$ & $1.23^{*}$ & 1.16 & 1.05 & 1.05 & $1.17^{\star *}$ & $1.20^{\star}$ & 1.16 & 1.16 & $1.29^{\star *}$ \\
\hline Q2: €13,952-18,346 & $1.12^{*}$ & 1.10 & 1.03 & 1.13 & 1.08 & 1.08 & 1.04 & 0.98 & 1.11 & 1.17 \\
\hline Q4: €22,666-29,653 & 0.95 & 0.98 & 0.92 & 0.92 & 1.01 & 0.98 & 0.96 & 0.85 & 1.00 & 1.09 \\
\hline Q5: More than $€ 29,654$ & $0.75^{\star \star \star}$ & $0.79^{\star *}$ & $0.65^{\star \star *}$ & $0.71^{\star \star \star}$ & 0.84 & $0.71^{* * *}$ & $0.75^{\star \star *}$ & $0.61^{* \star *}$ & $0.68^{* \star *}$ & $0.73^{\star *}$ \\
\hline \multicolumn{11}{|c|}{ House occupancy status (Ref: owner-occupier) } \\
\hline Private renting & $0.83^{\star \star *}$ & 0.89 & 0.91 & $0.79^{* \star *}$ & 0.89 & $0.81^{* * *}$ & 0.94 & 0.90 & $0.72^{* * *}$ & $0.81^{\star *}$ \\
\hline Public renting & 0.98 & 1.10 & 1.11 & 0.88 & $0.79^{*}$ & 0.96 & 1.06 & 0.95 & 0.88 & 0.89 \\
\hline \multicolumn{11}{|c|}{ Household member receiving unemployment benefits (Ref: no) } \\
\hline Yes & 0.99 & 1.00 & 1.07 & 0.99 & 1.02 & 0.98 & 1.01 & 1.13 & 0.96 & 0.96 \\
\hline \multicolumn{11}{|c|}{ Union duration (Ref: less than 4 years) } \\
\hline $4-6$ years & 1.07 & 0.96 & 0.94 & 1.16 & $1.31^{*}$ & 1.00 & 0.91 & 0.86 & 1.07 & 1.25 \\
\hline $7-10$ years & $1.31^{\star * *}$ & 1.18 & 1.06 & $1.42^{\star * *}$ & $1.40^{* *}$ & $1.28^{\star \star *}$ & $1.23^{*}$ & 1.09 & $1.33^{* * *}$ & $1.38^{\star *}$ \\
\hline Longer duration/unknown & $1.19^{\star \star}$ & 1.12 & 1.02 & $1.24^{\star *}$ & $1.28^{*}$ & $1.16^{\star *}$ & 1.14 & 1.04 & $1.18^{*}$ & $1.29^{*}$ \\
\hline
\end{tabular}


Ferrari, Bonnet \& Solaz: Residential mobility after divorce by parenthood status and custody arrangements

Table A-4: (Continued)

\begin{tabular}{|c|c|c|c|c|c|c|c|c|c|c|}
\hline & \multicolumn{5}{|c|}{ Fewer bedrooms per person } & \multicolumn{5}{|c|}{ Less space per person } \\
\hline & \multirow{2}{*}{ All } & \multicolumn{2}{|c|}{ Men } & \multicolumn{2}{|c|}{ Women } & \multirow{2}{*}{ All } & \multicolumn{2}{|c|}{ Men } & \multicolumn{2}{|c|}{ Women } \\
\hline & & All & Parents & All & Parents & & All & Parents & All & Parents \\
\hline \multicolumn{11}{|l|}{ Nationality (Ref: native) } \\
\hline Foreign-born & $1.43^{\star \star \star}$ & $1.70^{\star \star *}$ & $1.81^{\star \star \star}$ & $1.22^{\star \star}$ & $1.33^{\star *}$ & $1.40^{\star \star \star}$ & $1.61^{\star \star \star}$ & $1.88^{* \star *}$ & $1.22^{\star \star}$ & $1.23^{*}$ \\
\hline \multicolumn{11}{|c|}{ Town size (Ref: $200,000-1,999,999$ inhabitants) } \\
\hline Rural & 0.90 & 0.88 & $0.78^{*}$ & 0.91 & 0.86 & $0.90^{*}$ & 0.90 & 0.86 & 0.90 & $0.76^{\star *}$ \\
\hline $2,000-19,999$ inhabitants & 0.99 & 1.03 & 0.97 & 0.97 & 0.90 & 0.93 & 0.86 & 0.88 & 0.99 & 0.87 \\
\hline $20,000-199,999$ inhabitant & s0.90 & 0.86 & 0.88 & 0.95 & 0.96 & $0.86^{\star *}$ & $0.80^{* *}$ & $0.80^{*}$ & 0.92 & 0.90 \\
\hline Paris area & $1.66^{* * *}$ & $1.70^{\star \star \star}$ & $1.83^{* \star *}$ & $1.63^{* * *}$ & $1.85^{\star \star *}$ & $1.47^{\star \star \star}$ & $1.48^{* * *}$ & $1.82^{\star \star *}$ & $1.47^{\star \star *}$ & $1.76^{\star \star \star}$ \\
\hline \multicolumn{11}{|c|}{ Time spent in the accommodation (Ref: more than 10 years) } \\
\hline$<5$ years & $1.13^{*}$ & 1.15 & 1.05 & 1.10 & 1.12 & $1.29^{\star \star \star}$ & $1.28^{* *}$ & 1.09 & $1.30^{\star \star *}$ & $1.25^{\star \star}$ \\
\hline $5-9$ years & 1.08 & 1.14 & 1.07 & 1.01 & 1.03 & $1.23^{\star \star \star}$ & $1.21^{*}$ & 1.04 & $1.24^{\star \star}$ & 1.12 \\
\hline \multicolumn{11}{|c|}{ Type of union (Ref: marriage) } \\
\hline Civil union & $0.89^{*}$ & 0.93 & 0.88 & 0.86 & 0.96 & 0.95 & 0.92 & 0.81 & 0.96 & 1.22 \\
\hline $\begin{array}{l}\text { Number of bedrooms } \\
\text { p.p./space p.p. predivorce }\end{array}$ & $e^{9.71^{* \star *}}$ & $8.53^{\star * *}$ & $15.00^{* * *}$ & $11.2^{* * *}$ & $36.42^{\star \star \star}$ & $1.08^{\star \star \star}$ & $1.08^{\star * \star}$ & $1.11^{\star \star *}$ & $1.09^{\star \star *}$ & $1.16^{\star \star \star}$ \\
\hline Constant & $0.05^{* \star *}$ & $0.06^{\star \star *}$ & $0.02^{* * *}$ & $0.04^{* * *}$ & $0.01^{* * *}$ & $0.04^{* \star \star}$ & $0.05^{\star * *}$ & $0.01^{* \star *}$ & $0.03^{\star * *}$ & $0.01^{* * *}$ \\
\hline Observations & 12,570 & 5,864 & 3,931 & 6,706 & 4,320 & 12,570 & 5,864 & 3,931 & 6,706 & 4,320 \\
\hline
\end{tabular}

Note: ${ }^{* * *} p<0.01,{ }^{* *} p<0.05,{ }^{*} p<0.1$.

Source: French Permanent Demographic Sample (INSEE), 2010-2013

Table A-5: Comparison between the coefficients of child custody arrangements derived from models with and without an instrument on the local proportion of shared custody arrangements

\begin{tabular}{|c|c|c|c|c|c|}
\hline & & \multicolumn{2}{|c|}{ Men } & \multicolumn{2}{|c|}{ Women } \\
\hline & & Logit $^{a}$ & IV & Logit $^{a}$ & IV \\
\hline \multirow[t]{3}{*}{ Probability of moving } & Shared custody & $-0.946^{\star * \star}$ & $-0.198^{* * *}$ & $0.172^{* \star *}$ & $1.063^{* \star *}$ \\
\hline & Sole custody & $-0.882^{\star \star \star}$ & $-0.188^{\star \star *}$ & 0 & 0 \\
\hline & No custody & 0 & 0 & $0.196^{\star \star \star}$ & $0.938^{\star \star *}$ \\
\hline \multirow[t]{3}{*}{ Mean distance } & Shared custody & $-37.041^{\text {***}}$ & $-26.87^{\star \star \star}$ & $-45.80^{\star \star *}$ & $-55.876^{* * *}$ \\
\hline & Sole custody & 10.040 & 7.83 & 0 & 0 \\
\hline & No custody & 0 & 0 & $11.04^{*}$ & $23.766^{\star *}$ \\
\hline \multirow[t]{3}{*}{ Homeownership } & Shared custody & 0.063 & -0.013 & -0.006 & -0.028 \\
\hline & Sole custody & $-0.274^{\star *}$ & $-0.052^{*}$ & 0 & 0 \\
\hline & No custody & 0 & 0 & -0.021 & -0.071 \\
\hline \multirow[t]{3}{*}{ Fewer bedrooms per person } & Shared custody & $1.507^{\star \star \star *}$ & $0.023^{*}$ & -0.057 & $0.162^{*}$ \\
\hline & Sole custody & $1.638^{* * *}$ & $0.060^{* \star *}$ & 0 & 0 \\
\hline & No custody & 0 & 0 & $-0.005^{\star \star \star}$ & $-0.943^{\star \star *}$ \\
\hline \multirow[t]{3}{*}{ Less space per person } & Shared custody & $1.778^{* * *}$ & $0.267^{\star \star *}$ & 0.010 & 0.094 \\
\hline & Sole custody & $1.985^{\star \star \star}$ & $0.332^{\star \star \star}$ & 0 & 0 \\
\hline & No custody & 0 & 0 & $-0.256^{\star \star \star}$ & $-1.533^{\star \star *}$ \\
\hline
\end{tabular}

Notes: ${ }^{a}$ These are results from logit models that include the same controls as previous models, except the analysis on the mean distance which shows results from an OLS regression. ${ }^{* *} p<0.01,{ }^{* *} p<0.05,{ }^{*} p<0.1$.

Source: French Permanent Demographic Sample (INSEE), 2010-2013 